Civil Works Hydropower R\&D Program

\title{
Cavitation-Resistant Coatings for Hydropower Turbines
}

Ryan Sollars and Alfred D. Beitelman

June 2011

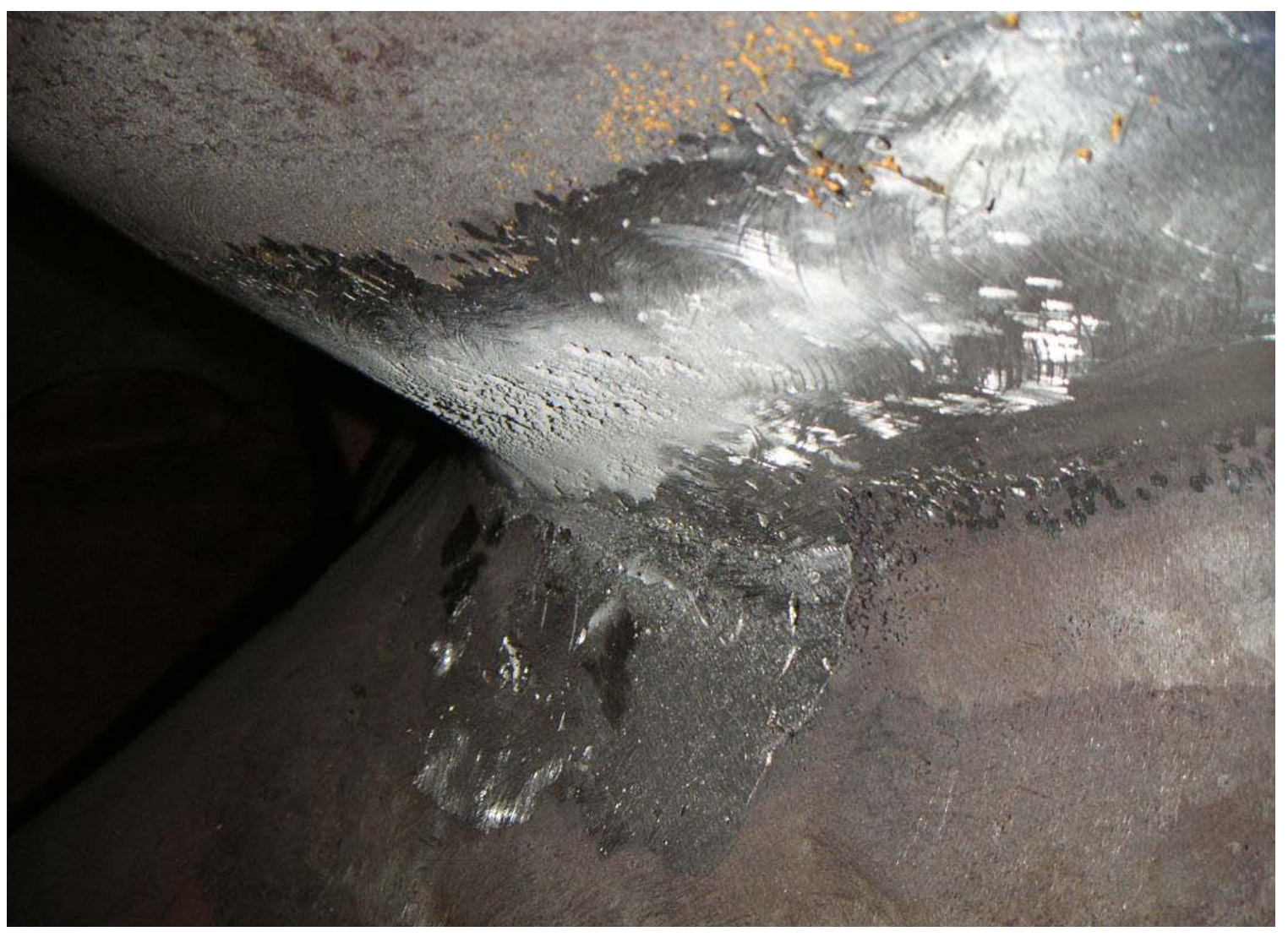





\title{
Cavitation-Resistant Coatings for Hydropower Turbines
}

\author{
Ryan Sollars \\ US Army Corps of Engineers \\ Portland District \\ Hydroelectric Design Center \\ 333 SW First Avenue \\ Portland, Oregon 97204-3440 \\ Alfred D. Beitelman \\ US Army Engineer Research and Development Center \\ Construction Engineering Research Laboratory \\ 2902 Newmark Drive \\ Champaign, Illinois 61822-1076
}

Final report

Approved for public release; distribution is unlimited.

Prepared for US Army Corps of Engineers

Washington, DC 20314-1000 


\begin{abstract}
Operating hydropower turbines to obtain the ultimate power output often results in cavitation (the rapid formation and collapse of vapor pockets in a flowing liquid in regions of very low pressure) in the turbine area. The level of cavitation typically destroys organic coatings in a relatively short time. Traditional metallizing to repair cavitation damage has resulted in unsatisfactory performance. Other coating systems, such as those deposited by High Velocity Oxygen Flame (HVOF), have been laboratory tested and shown to hold promise but have not been evaluated in actual long-term field applications.
\end{abstract}

This study evaluated HVOF-applied coating systems that hold promise for long-term cavitation resistance and apply the most promising products to turbine areas for long-term field performance data. Work consisted of evaluating existing published and unpublished data on cavitation-resistant materials and selecting the most promising systems for field application. Those systems were then applied to areas of a turbine to evaluate their long-term performance.

After 1year, it is clear that many of the coatings have failed. Two of the coatings, however, appear to be virtually unchanged from the time of application and may be found to provide long-term resistance to damage caused by cavitation.

DISCLAIMER: The contents of this report are not to be used for advertising, publication, or promotional purposes. Citation of trade names does not constitute an official endorsement or approval of the use of such commercial products. All product names and trademarks cited are the property of their respective owners. The findings of this report are not to be construed as an official Department of the Army position unless so designated by other authorized documents. 


\section{Table of Contents}

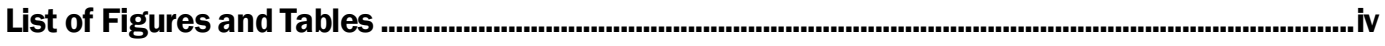

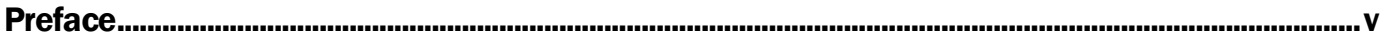

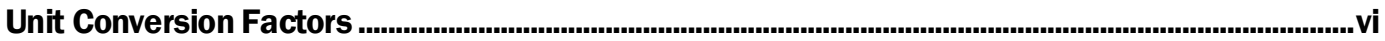

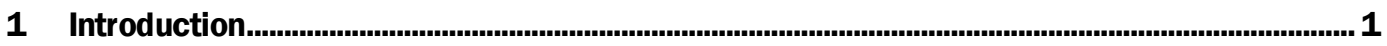

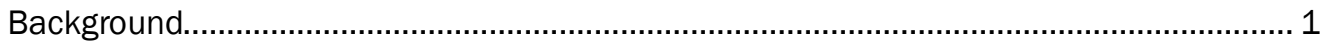

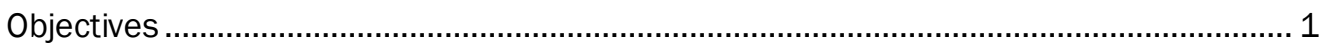

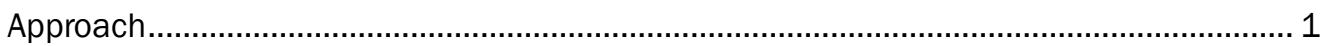

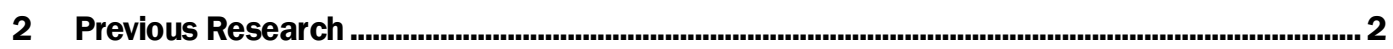

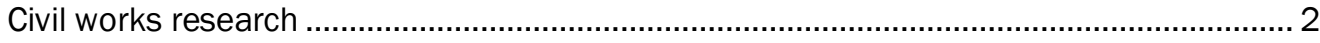

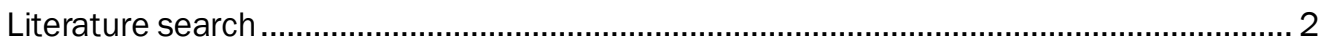

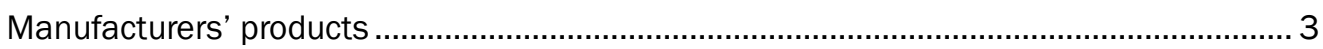

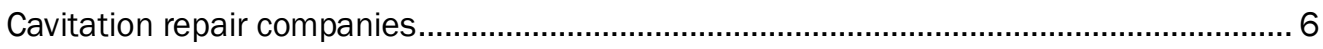

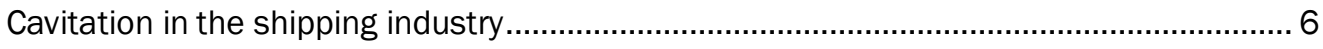

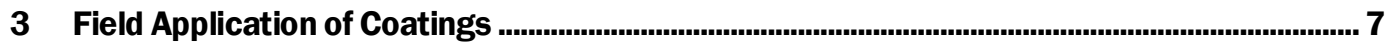

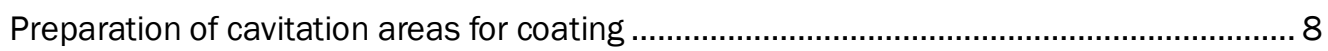

Application of HVOF coatings.................................................................................. 10

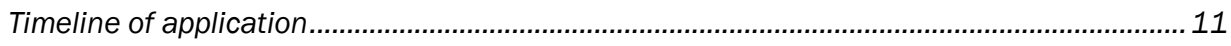

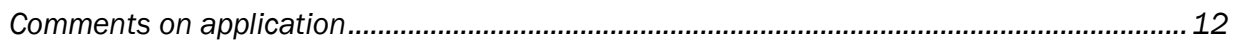

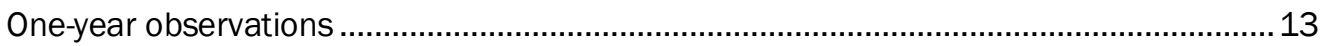

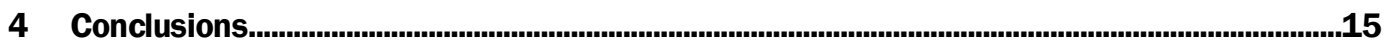

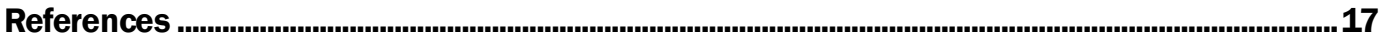

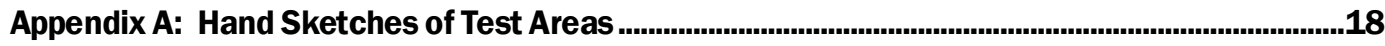

Appendix B: Material Documentation and Application Equipment Settings ............................23

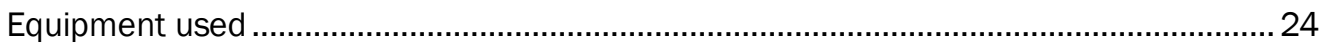

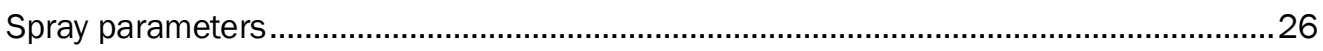

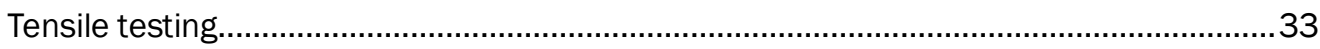

Microstructure and hardness ................................................................................. 42

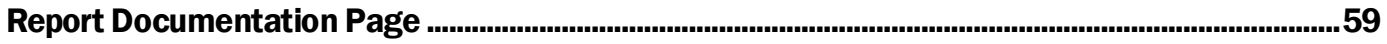




\section{List of Figures and Tables}

\section{Figures}

1 Typical cavitation damage areas on lower one-third of suction side of buckets after approximately 1 year of operation since last repair.

2 Typical cavitation damage areas on upper one-third of suction side of buckets after approximately 1 year of operation since last repair.............................................................................

3 Typical cavitation damage area showing that cavitation-prone area covers much of area near fillet on suction side of buckets 9

$4 \quad$ Typical cavitation repair areas on discharge side of buckets …...........................................................10

\section{Tables}

1 Manufacturers of anti-cavitation and surface hardening coatings .4

2 Cavitation-resistant coatings tested at Green Peter Unit 2 


\section{Preface}

This demonstration was conducted for the Directorate of Civil Works, Headquarters, US Army Corps of Engineers (CECW) under the Civil Works Hydropower R\&D Program. The proponent and technical monitor was Kamau B. Sadiki (CECW-CO-H).

The performing laboratory was the Materials and Structures Branch (CF-M) of the Facilities Division (CF), Construction Engineering Research Laboratory (CERL). The Project Manager was Alfred D. Beitelman (CF-M). Ryan Sollars of the Corps of Engineers Portland District Hydroelectric Design Center coordinated the field work. At the time this report was prepared, the Chief of CF-M was Vicki L. VanBlaricum, the Chief of CF was L. Michael Golish, and the Technical Director for Installations (CV-ZT) was Martin J . Savoie. The Deputy Director of CERL was Dr. Kirankumar Topudurti and the Director was Dr. Ilker Adiguzel.

CERL is an element of the US Army Engineer Research and Development Center (ERDC). The Commander and Executive Director of ERDC was COL Kevin J. Wilson and the Director was Dr. J effery P. Holland. 


\section{Unit Conversion Factors}

\begin{tabular}{|l|c|l|}
\hline Multiply & By & To Obtain \\
\hline feet & 0.3048 & meters \\
\hline horsepower (550 foot-pounds force per second) & 745.6999 & watts \\
\hline inches & 0.0254 & meters \\
\hline microinches & 0.0254 & micrometers \\
\hline mils & 0.0254 & millimeters \\
\hline square inches & $6.4516 \mathrm{E}-04$ & square meters \\
\hline
\end{tabular}




\section{Introduction}

\section{Background}

Hydropower turbines are often operated in a manner to obtain the ultimate amount of power output. Unfortunately, this frequently results in cavitation (the rapid formation and collapse of vapor pockets in a flowing liquid in regions of very low pressure) in the turbine area. The level of cavitation typically destroys organic coatings in a relatively short time. Traditional metallizing also has resulted in unsatisfactory performance. Other coating systems, such as those deposited by High Velocity Oxygen Flame (HVOF), have been laboratory tested and shown to hold good promise but have not been evaluated in actual long-term field applications. Field data would add validity to the laboratory data and perhaps provide long-term cavitation resistance.

\section{Objectives}

The objectives of this work were to evaluate HVOF-applied coating systems that hold promise for long-term cavitation resistance and apply the most promising products to turbine areas for long-term field performance data.

\section{Approach}

Work consisted of evaluating existing published and unpublished data on cavitation-resistant materials and selecting the most promising systems for field application. Those systems were then applied to areas of a turbine to evaluate their long-term performance. 


\section{Previous Research}

\section{Civil works research}

There were no previous studies on this subject found in the Corps of Engineers civil works research program. Work had been done in other programs, most notably in the Construction Productivity Advancement Research Program, which was published in a technical report entitled "Cavitation- and Erosion-Resistant Thermal Spray Coatings" (Boy et al. 1997). The report states the current practice for cavitation repair to be 308 and 309 weld rods, but laboratory data showed HVOF coatings to offer superior cavitation resistance as well as corrosion protection in the area of dissimilar metal boundaries. Although HVOF was used to demonstrate the field application of several coating materials, no data on the performance of the field applications were published.

Current cavitation repair practice within the Corps of Engineers typically consists of standard welding procedures. Cavitation repair performed recently at Corps of Engineers' power plants include dams at Green Peter, Foster Lakes, OR; Lower Granite, Clarkston, WA; Ice Harbor, Burbank, WA; Lookout Point, Dexter, OR; Hills Creek, Lake, OR; and Carters, Ellijay, GA. The Corps' corporate practice has been almost exclusively to use 308 and 309 weld rod for cavitation repair. No other material has been commonly used. The only example of other materials used for cavitation repair was Hydroloy weld rod used at Carters Dam in 2003.

\section{Literature search}

A literature search was conducted to identify some recent studies and documents on metallic cavitation resistant coatings:

1. A. Kumar, Exotic Alloys for Cavitation Resistance: Passing the Tests, Hydro Review, Vol. 17:5 (1998):16- 21.

2. P. March and J . Hubble, Evaluation of Relative Cavitation Erosion Rates For Base Materials, Weld Overlays, and Coatings, Report No. WR28-1-900-282, Norris, TN: Tennessee Valley Authority Engineering Laboratory (September 1996).

3. T. Spicher, Hydro Wheels: A Guide to Maintaining and Improving Hydro Units, Kansas City, MO: HCI Publications (1995). 
4. R. Richard, P. Willis, and A. Kumar, Application of Thermal Spray and Ceramic Coatings and Reinforced Epoxy for Cavitation Damage Repair of Hydroelectric Turbines, USACERL Technical Report TR FM93/ 01, Champaign, IL: US Army Construction Engineering Research Laboratory (March 1993).

5. Ashok Kumar, J. Boy, Ray Zatorski, and L.D. Stephenson, Thermal Spray and Weld Repair Alloys for the Repair of Cavitation Damage in Turbines and Pumps: A Technical Note, J ournal of Thermal Spray Technology, Vol. 14(2): 177- 182 (J une 2005).

6. C. L. Cheng, C.T. Webster, and J.Y. Wong, Reduction of Cavitation Erosion Damage on Hydraulic Structures through the Use of Coatings, Report CEA No. 511G530, Montreal, Quebec: Canadian Electrical Association (May 1987).

7. P. R. Rodrigue, Cavitation Pitting Mitigation in Hydraulic Turbines, Final Report EPRIAP-4719 Project 1745-10, Vol. 1\&2, Palo Alto, CA: Electric Power Research Institute (August 1986).

8. J. S. Baker, Cavitation Resistant Properties of Coating Systems Tested on a Venturi Cavitation Testing Machine, Denver, CO: Bureau of Reclamation, Research Laboratory and Services Division (J anuary 1994).

9. O. F. Karr, J. B. Brooks, P. A. March, and J . M. Epps, Raccoon Mountain Pumped Storage Plant, Unit 3 Weld Overlay Field Test Inspection Report, Tennessee Valley Authority Report No. TVA/ PBO/R\&D-90/4 (May 1990).

10. R. Schwetzke and H. Kreye, Cavitation Erosion of HVOF Coatings, Conference paper from Thermal Spray 1996: Practical Solutions for Engineering Problems, C. C. Berndt, Ed., ASM International, 153- 158.

\section{Manufacturers' products}

A search of manufacturers of anti-cavitation and surface hardening coatings was conducted. It was determined that a large number of vendors sell products that are potentially useful for metallic anti-cavitation coatings. Table 1 lists those vendors found. These vendors all manufacture thermal coatings for surface hardening for cavitation or wear. There are more vendors than it was possible to test in a field location. Further reduction of potential vendors would be possible by ranking their cavitation performance versus a cavitation standard such as ASTM G32, and choosing the highest ranking vendors for comparative in-field testing. Each of the vendors was contacted asking for information on their anti-cavitation products being testing according to ASTM G32. The results of the inquiries are included in the notes in Table 1. 
Table 1. Manufacturers of anti-cavitation and surface hardening coatings.

\begin{tabular}{|c|c|c|c|}
\hline Vendor & Product(s) & Contact & Notes \\
\hline Powder Alloy Inc. & $\begin{array}{l}\text { Thermal coatings, HVOF powders, } \\
\text { plasma spray powders, plasma } \\
\text { transferred arc powders, and } \\
\text { metallizing wire }\end{array}$ & $\begin{array}{l}\text { Scott } \\
\text { Ostholthoff }\end{array}$ & $\begin{array}{l}\text { Does not currently have any } \\
\text { products tested to ASTM G32; } \\
\text { though they do have anti- } \\
\text { cavitation coatings }\end{array}$ \\
\hline Voith Siemens - & Anti-cavitation coatings & & $\begin{array}{l}\text { Voith is a turbine manufacturer } \\
\text { having experience with cavitation } \\
\text { problems. }\end{array}$ \\
\hline Plasma-Tec & $\begin{array}{l}\text { Ceramic Chrome Oxide thermal } \\
\text { coatings }\end{array}$ & $\begin{array}{l}\text { Christopher } \\
\text { Wysong }\end{array}$ & $\begin{array}{l}\text { Does not have any specific } \\
\text { products for anti-cavitation; they } \\
\text { recommended Wall Colomonoy } \\
\text { products. }\end{array}$ \\
\hline $\begin{array}{l}\text { Surface } \\
\text { Modification } \\
\text { Systems }\end{array}$ & Thermal coatings & \begin{tabular}{|l|} 
Rajan \\
Bamola
\end{tabular} & $\begin{array}{l}\text { Interested in helping with any } \\
\text { studies; they recommended } \\
\text { testing Amacor M, Nanosteel. } \\
\text { Have done recent R\&D combining } \\
\text { metallic spray systems with a } \\
\text { nonmetallic (epoxy) overcoat. }\end{array}$ \\
\hline $\begin{array}{l}\text { Plasma Thermal } \\
\text { Coatings }\end{array}$ & Alumina Titania coatings & & No response. \\
\hline Alacote & Thermal coatings & & No response. \\
\hline Stellite & Thermal spray materials & \begin{tabular}{|l|} 
Ken \\
Whittenburg
\end{tabular} & $\begin{array}{l}\text { Recommended Ultimet by Haynes } \\
\text { or Deloro Stellite. }\end{array}$ \\
\hline $\begin{array}{l}\text { Flame Spray } \\
\text { Technologies }\end{array}$ & Thermal coatings & Jim Perks & $\begin{array}{l}\text { Primarily manufacturer of flame } \\
\text { spray equipment; others provide } \\
\text { the weld rod and powder } \\
\text { materials. Interested in our } \\
\text { research and willing to provide } \\
\text { support on tools. They noted new } \\
\text { HVOF system, JP5000, would } \\
\text { allow thicknesses up to } 0.5 \text { in.; } \\
\text { these new technology systems } \\
\text { were not available during last } \\
\text { series of anti-cavitation coating } \\
\text { tests in } 1997 .\end{array}$ \\
\hline $\begin{array}{l}\text { Climax Engineered } \\
\text { Materials }\end{array}$ & $\begin{array}{l}\text { Thermal coatings, unique metal } \\
\text { powders and products }\end{array}$ & & No response. \\
\hline$\underline{\text { Thermion }}$ & Thermion thermal coatings & & No response. \\
\hline $\begin{array}{l}\text { Ameteck Specialty } \\
\text { Metal Products }\end{array}$ & $\begin{array}{l}\text { Thermal coatings, including } \\
\text { equivalents to Hastelloy and Inconel }\end{array}$ & & No response. \\
\hline $\begin{array}{l}\text { Bay State Surface } \\
\text { Technology }\end{array}$ & Thermal coatings & & No response. \\
\hline $\begin{array}{l}\text { Carpenter Powder } \\
\text { Products }\end{array}$ & Thermal coatings & & No response. \\
\hline $\begin{array}{l}\text { Saint Gobain } \\
\text { Coatings }\end{array}$ & Thermal coatings & & No response. \\
\hline
\end{tabular}




\begin{tabular}{|c|c|c|c|}
\hline Vendor & Product(s) & Contact & Notes \\
\hline $\begin{array}{l}\text { Ellison Surface } \\
\text { Technologies }\end{array}$ & Thermal coatings & & No response. \\
\hline Exline, Inc. & Thermex thermal coatings & $\begin{array}{l}\text { Larry } \\
\text { Pankratz }\end{array}$ & $\begin{array}{l}\text { Exline does not currently have } \\
\text { any products tested to ASTM G32, } \\
\text { but they are interested in anti- } \\
\text { cavitation coatings and testing. }\end{array}$ \\
\hline$\underline{\text { Sulzer Metco }}$ & $\begin{array}{l}\text { Thermal coatings, including } \\
\text { Champro, Amdry, Mectoloy, and } \\
\text { Thermospray }\end{array}$ & & No response. \\
\hline Haiams & Thermal coatings & $\begin{array}{l}\text { Daren } \\
\text { Gansert }\end{array}$ & $\begin{array}{l}\text { They market HA-1800 and were } \\
\text { interested in future testing of } \\
\text { their product. }\end{array}$ \\
\hline Haynes Wire & $\begin{array}{l}\text { Thermal coatings, maker of Ultimet } \\
\text { and Hastalloy weld rod }\end{array}$ & $\begin{array}{l}\text { Paul } \\
\text { Manning }\end{array}$ & $\begin{array}{l}\text { Recommended Deloro Stellite } \\
\text { and the Ultimet product line as } \\
\text { another possible product to test. }\end{array}$ \\
\hline Höganäs & $\begin{array}{l}\text { Thermal coatings, maker of } \\
\text { Höganäs thermal surfacing powders }\end{array}$ & $\begin{array}{l}\text { Lars-Ake } \\
\text { Nilsson }\end{array}$ & $\begin{array}{l}\text { None of their material has been } \\
\text { tested to ASTM G32. }\end{array}$ \\
\hline Mettech & $\begin{array}{l}\text { Thermal coatings, maker of } \\
\text { proprietary Axial III Thermal Spray } \\
\text { Systems }\end{array}$ & & No response. \\
\hline Osram Sylvania & $\begin{array}{l}\text { Thermal coatings, maker of Osram } \\
\text { Sylvania spray powders }\end{array}$ & & No response. \\
\hline Plasma-Tec & $\begin{array}{l}\text { Thermal coatings, maker of ALPHA } \\
1800 \text { arc spray coatings }\end{array}$ & & No response. \\
\hline $\begin{array}{l}\text { PolyMet } \\
\text { Corporation }\end{array}$ & $\begin{array}{l}\text { Thermal coatings, maker of PMET } \\
\text { thermal spray wires }\end{array}$ & $\begin{array}{l}\text { Richard } \\
\text { Cook }\end{array}$ & $\begin{array}{l}\text { No specific product has been } \\
\text { tested to ASTM G32; they are } \\
\text { interested in cavitation coatings. }\end{array}$ \\
\hline UCT Coatings & $\begin{array}{l}\text { Thermal spray anti-cavitation } \\
\text { coatings }\end{array}$ & $\begin{array}{l}\text { Wynn } \\
\text { Atterbury }\end{array}$ & $\begin{array}{l}\text { They have coatings tested to } \\
\text { ASTM G32; interested in future } \\
\text { testing, but their current product } \\
\text { does not allow for field } \\
\text { application. }\end{array}$ \\
\hline $\begin{array}{l}\text { Wall Colmonoy } \\
\text { Corporation }\end{array}$ & Colmonoy & & $\begin{array}{l}\text { Wall Colmonoy was not part of } \\
\text { the market survey; they were } \\
\text { recommended by Plasma-tec. }\end{array}$ \\
\hline Amperit & $\begin{array}{l}\text { AMPERIT and AMPERWELD hard } \\
\text { surface coatings }\end{array}$ & & $\begin{array}{l}\text { Amperit was not part of the } \\
\text { market survey }\end{array}$ \\
\hline Alstrom & $\begin{array}{l}\text { Neyroco anti-cavitation coatings } \\
\text { (nonmetallic, for reference only) }\end{array}$ & & $\begin{array}{l}\text { Alstrom is a large turbine } \\
\text { manufacturer with extensive } \\
\text { experience with cavitation } \\
\text { coatings and design issues. }\end{array}$ \\
\hline
\end{tabular}


During the process of investigating metallic cavitation repair and prevention coatings, it was noted that there are many nonmetallic anti-cavitation coatings. Comparative testing between the metallic and nonmetallic coatings could be valuable, as nonmetallics used in small pump applications are a well-developed market segment and could be as good as or better than metallic anti-cavitation coatings. See this article for a typical example of a nonmetallic coating. Further market research into nonmetallic anticavitation coatings is beyond the scope of this program.

\section{Cavitation repair companies}

Two cavitation repair companies were contacted to determine the methods they commonly use for cavitation repair. Mike Triggs, from Hydro Power Services (HPS), said they traditionally have used 308 and 309; however, HPS recommended using 309 only. HPS has used other exotic welding materials (e.g., Cavtec) with little success. Mallory Davis, from Powerhouse Inc., uses 309 for cavitation repair and does not recommend the exotic welding materials. Neither vendor had used thermal spray or other unique repair methods.

\section{Cavitation in the shipping industry}

The US Navy repair yards in Washington State and Hawaii, as well as Dr. Richard P. Szwerc of the US Navy Advanced Propulsor Development Office, were contacted to determine what methods the Navy uses for cavitation repair. The response from the Navy was that, in general, their propellers did not cavitate; cavitation was not a problem. The few cavitation problems that they did have were generally repaired by traditional welding. For new propellers, the Navy has partnered with Rolls Royce to work on a new thermal spray anti-cavitation coating. Click on this link for more information.

In 2003, the Naval Sea Systems Command and National Surface Treatment Center gave a presentation entitled, "Rudder Coating Failures on Navy Ships." This report details some of the research the Navy performed on metallic and nonmetallic coatings. The Navy was unsuccessful in finding a reliable, corrosion- and cavitation-resistant metallic coating. 


\section{Field Application of Coatings}

The Green Peter Dam was selected to test cavitation resistant coatings. Green Peter is on the Middle Santiam River in Oregon and is operated by the Corps of Engineers Portland District. Construction on the project was initiated in 1961 and completed in 1967. It has two 133-in.-diameter Francis runners rated at 55,000 $\mathrm{HP}$ at $265 \mathrm{ft}$ head.

No formal cavitation inspection documentation was found; however, initial cavitation damage was documented with handwritten annotations within a few years of unit start up. At some point, perhaps 10 years ago, the runners were repaired for leading edge cavitation, which was thought to be due to temporary operational constraints. No additional information is known. The leading edges of the runners were repaired and have not shown damage since. The cavitation damage on the discharge side has been reoccurring and has continued to occur in approximately the same areas.

Cavitation damage on the suction side has been repaired with stainless steel weld overlay many times. For many years, this was done on a biannual basis, but recently repair has been performed yearly. The stainless overlay has reduced cavitation damage on the suction side of the runner. No photographs are available of the early cavitation repairs. However, some cost data are available for earlier fiscal years (FYs):

March 1999 to September 2001: \$215,172.98

FY02: \$140,907.87

FY04 to FY06: No work performed

FY07: \$221,537.32

FY08: $\$ 98,621$

Over the 10-year period, the Government spent at least \$676,239.17 on cavitation repairs. Additional money was spent in FY09 with work performed by Government personnel. 


\section{Preparation of cavitation areas for coating}

Work was conducted on Green Peter Unit 2 in November 2009. Nine turbine runner buckets were repaired and included in the testing. The following levels of cavitation (see Figures 1 through 4) were observed:

RUNNER DISCHARGE SIDE AT BAND: Cavitation was present on every bucket, on the fillet between the bucket and the band. The area and extent of the damage was approximately the same in all locations.

RUNNER DISCHARGE SIDE AT CROWN: There was no evidence of cavitation damage on the suction side of the trailing edge of the blades at their connection to the crown.

RUNNER INLET SIDE AT CROWN: There was no evidence of cavitation damage on the suction side of the trailing edge of the blades at their connection to the crown.

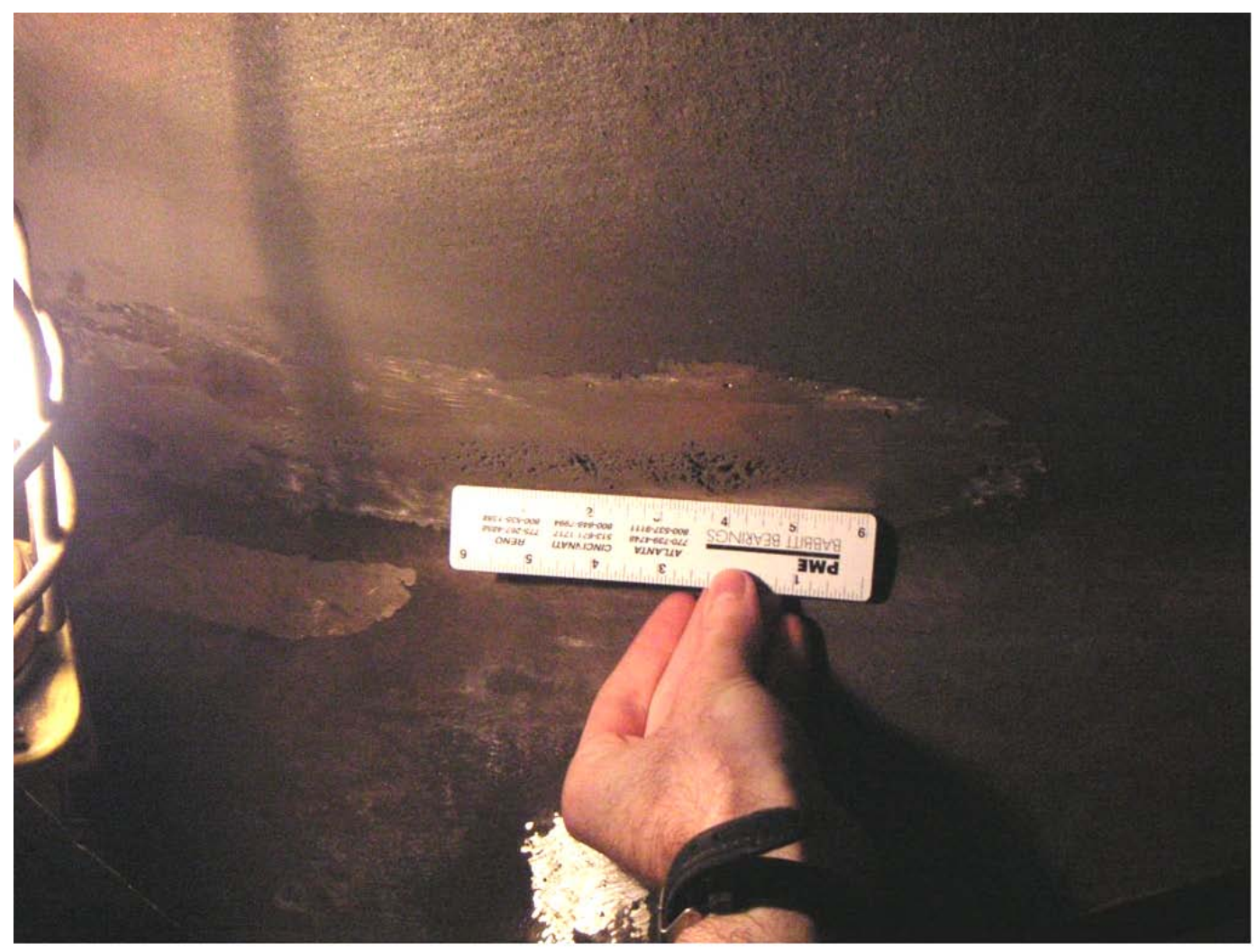

Figure 1. Typical cavitation damage areas on lower one-third of suction side of buckets after approximately 1 year of operation since last repair. 


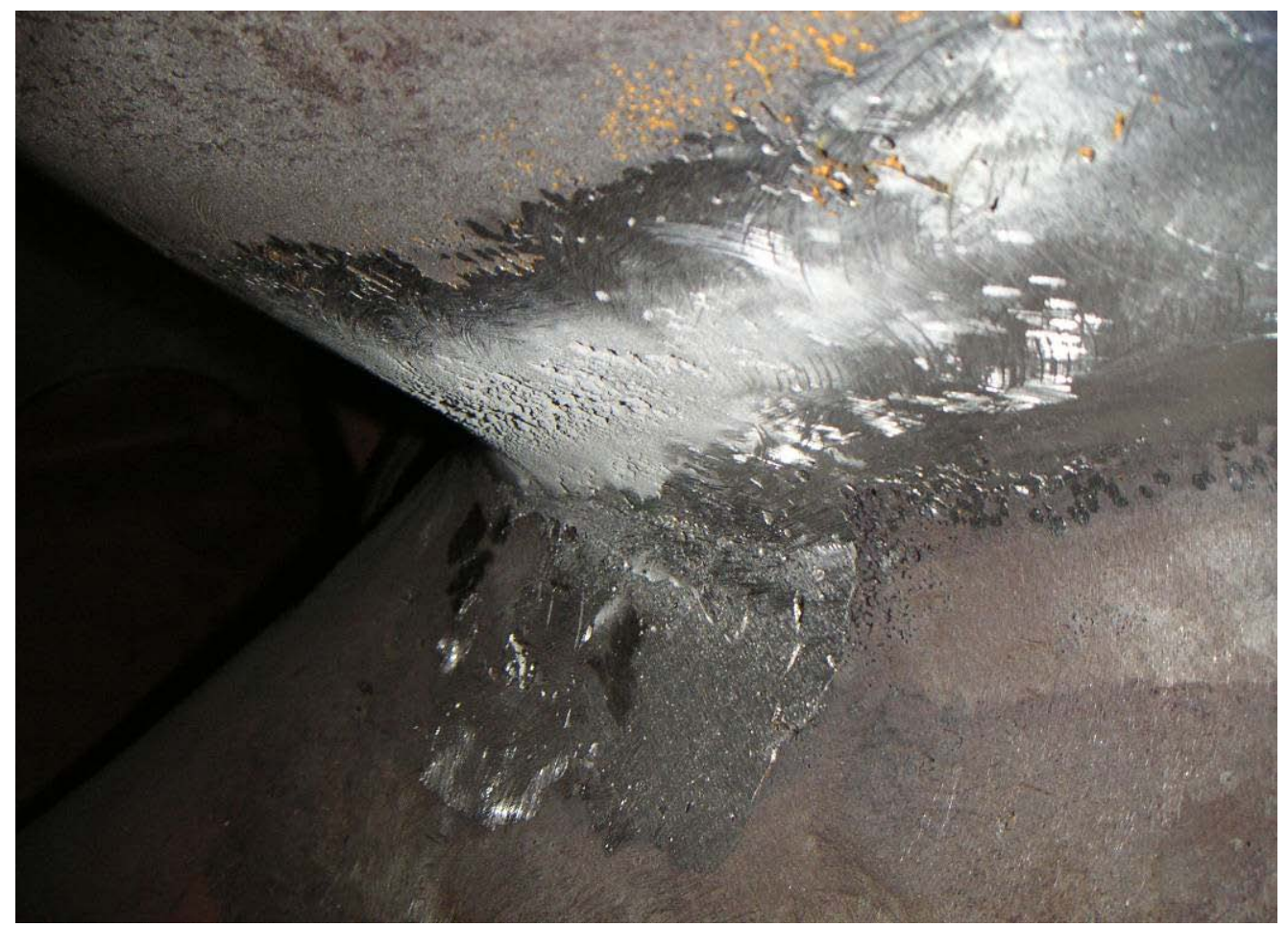

Figure 2. Typical cavitation damage areas on upper one-third of suction side of buckets after approximately 1 year of operation since last repair.

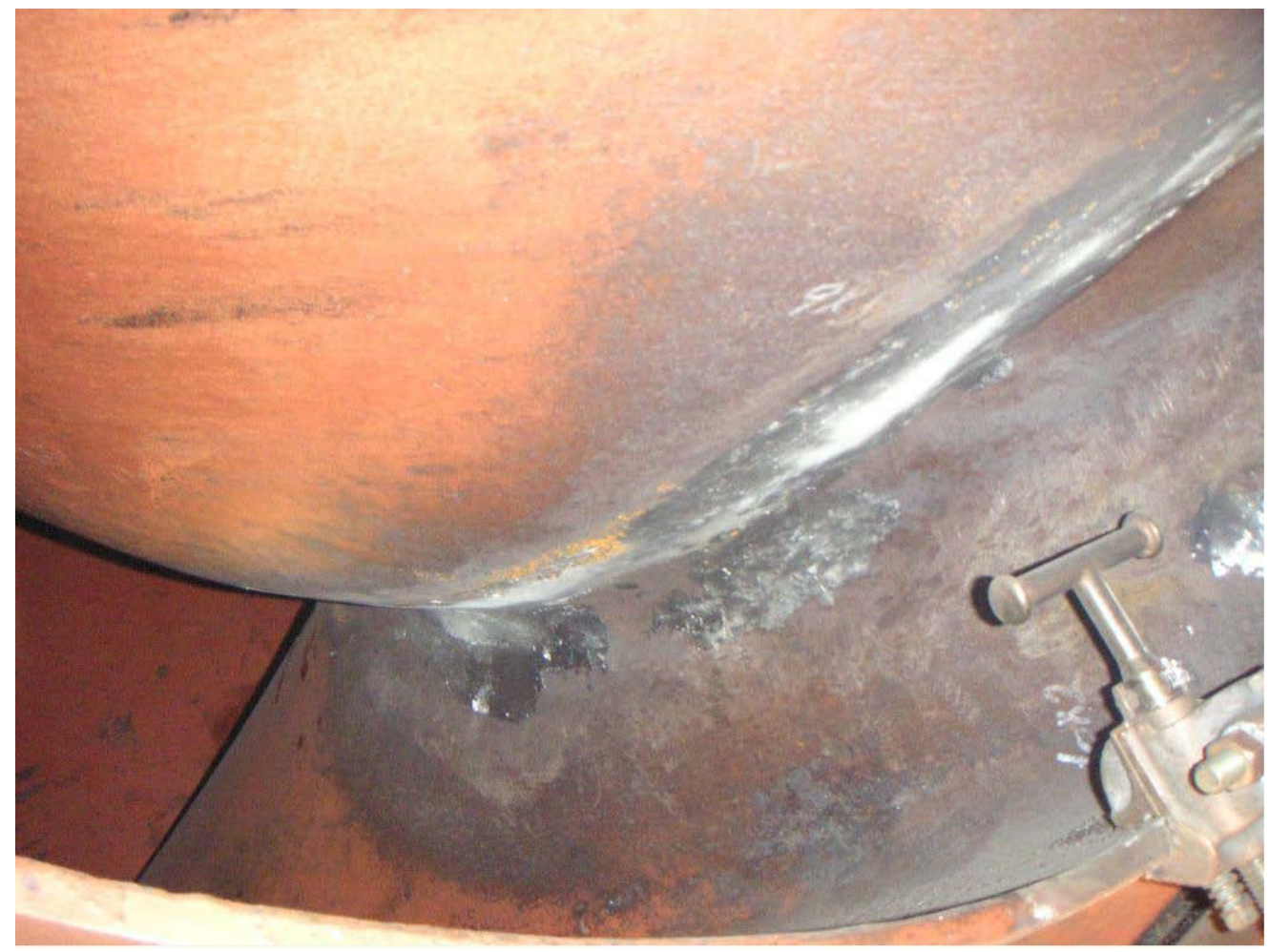

Figure 3. Typical cavitation damage area showing that cavitation-prone area covers much of area near fillet on suction side of buckets. 


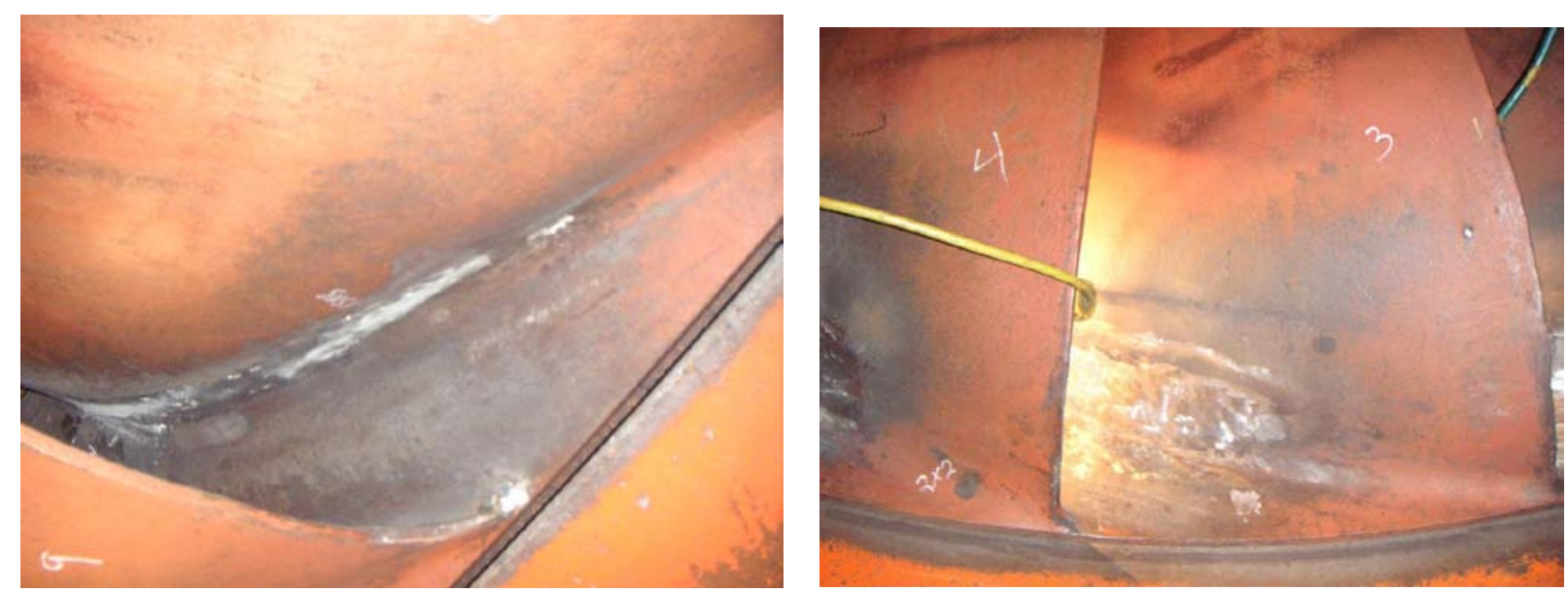

Figure 4. Typical cavitation repair areas on discharge side of buckets.

Prior to application of the coatings, the existing cavitation was repaired on each of the test buckets. The base metal of the runner is cast steel, QQ-5681 , class 3 . The repair conducted by site personnel consisted of fill welding the area with 309 stainless and grinding the repair smooth. The coating applicator Flame Spray Incorporated (FSI) then abrasive blasted the surfaces with aluminum oxide grit. The surface roughness of the substrate before coating as well as that of the applied coating was recorded and documented by FSI (see Appendix A). The sketches in this appendix show the average roughness $(\mathrm{Ra})$ in microinches $(1000 \mu \mathrm{in}$. is equivalent to $1 \mathrm{mil}$ or $0.001 \mathrm{in}$.). The sketches include a line indicating the direction the instrument was oriented while making the reading. The sketches also show the location of a number of spots indicating cavities remaining in the surface after the grinding and abrasive blasting. Such cavities are inevitable. Some of the larger holes show an estimated diameter $(\varnothing)$ and depth $(\downarrow)$ in inches; however, the majority of the holes that are shown simply as spots were too small to accurately estimate.

\section{Application of HVOF coatings}

Due to the size of the runner, only the cavitation on the bottom of the suction side of the blades was coated with resistant coatings. The cavitation near the leading edge and runner band is in a space restricted area, and the HVOF gun cannot easily reach this area; also, HVOF requires approximately an 18-in. offset for application.

The applicator attempted to apply each coating to a final thickness of 20 mils. Since it is not possible to measure this thickness without damaging the coating, the applicator developed a procedure of coating a piece of flat 
steel and measuring the added thickness with a micrometer after a given number of passes with the gun. After determining the number of passes required to deposit a 20-mil coating at a consistent spray speed, the applicator coated the test area and assumed the desired 20-mil coating was accomplished. Table 2 lists the coatings tested. Appendix B documents the application equipment used, the coating products applied and the equipment settings used for the application of each product. Coating materials applied to test specimens were also subjected to tensile testing, which is also documented.

Table 2. Cavitation-resistant coatings tested at Green Peter Unit 2.

\begin{tabular}{|l|l|}
\hline Bucket \# & Coating \\
\hline 1 & Nanosteel SHS 9172 \\
\hline 2 & Vecalloy \\
\hline 3 & Ultimet \\
\hline 4 & Stellite 6 \\
\hline 5 & Praxair 1350 VM \\
\hline 6 & Amperit 588: $\mathrm{Cr} 3 \mathrm{C} 2-\mathrm{NiCr} 75 / 25$ \\
\hline 7 & Amperit 584: $\mathrm{Cr} 3 \mathrm{C} 2-\mathrm{NiCr} 75 / 25$ \\
\hline 8 & Stellite 21 \\
\hline 16 & 309 (base material for reference) \\
\hline
\end{tabular}

\section{Timeline of application}

Monday 11-16-09: By 9:30 AM the Contractor had already started to unload equipment from a flatbed truck. The air-gas truck arrived with seven oxygen tank assemblies. The equipment was lowered into the penstock gallery. The HVOF console and the powder feeder were set up near the draft tube door. In the afternoon, it was discovered that the air tanks were too tall to pass underneath the penstocks. As a result, longer air hose was procured and delivered overnight from San Diego.

Tuesday 11-17-09: Following a site safety meeting to go over the work and any potential hazards, work was initiated to abrasive blast the sample areas with aluminum oxide abrasive for HVOF application. The repair area was measured and mapped (see Appendix A) for weld inclusions and defects as well as the surface finish. The HVOF equipment started, but a water pressure alarm kept the system from operating properly. It was found that a check valve in the water lines was obstructing the water flow. The 
HVOF machine was connected to another water source and was tested, but it was too late in the day so the equipment was left set up for the following morning.

Wednesday 11-18-09: The sample areas were lightly blasted to remove any oxide that might have formed overnight. Each bucket was marked with an area of about $12 \mathrm{in.} \times 4$ in. At the time of initial application, the temperature was $56.9^{\circ} \mathrm{F}$, humidity $63.3 \%$, and dew point $48^{\circ} \mathrm{F}$. Bucket \#1 was coated with Nanosteel 9172. The total application time was approximately 25 minutes. As bucket \#7 was coated with Amperit 584, the applicator noted what appeared to be a small crack in the test application area, apparently from the existing weld repair. A photograph was taken and the coating material was applied. Bucket \#5 was coated with Praxair 1350 VM. Bucket \#6 was coated with Amperit 588. Bucket \#4 was coated with Stellite 6. There was a miscommunication with the applicator, which resulted in bucket \#8 being coated with Stellite 21. This bucket had not been repaired and had very minor cavitation. Bucket \#3 was coated with Ultimet. Bucket \#2 was coated with Vecalloy. All applications were finished in approximately 5 hours.

For each test material, the material was sprayed on the test area as well as on test specimens that will be tested by FSI for thickness and strength. Photographs were taken of each area before and after the HVOF coating application. Photographs were also taken of all the equipment and the process was videotaped. The coating was finished late afternoon, and the work area was cleaned and some equipment dismantled.

Thursday 11-9-09: The equipment was loaded onto a flatbed truck and the area cleaned. FSI left the Green Peter site at approximately 1PM.

During the week of 11-23: An additional bucket (\#16) was weld repaired to be the reference 309 bucket since all of the repaired buckets were used for testing materials. Reference photographs were taken of the bucket before and after the repair.

\section{Comments on application}

There was very little visible smoke and the noise is similar to air-arcing, although slightly less. 
The process has similar ventilation requirements to welding, without the danger of arc flash or a need for ultraviolet light protection. Heat is not intense when outside of the flame tip and does not require special shielding. The gun causes no damage when the tip of the flame is several feet from a surface.

The sample areas were chosen on the bottom of the runner because the JP5000 gun cannot reach the cavitation areas on the leading edge; the gun is too large and there is a minimum offset of approximately $18 \mathrm{in}$. The minimum offset would be a disadvantage for some smaller turbines where space is very restricted.

The feeder and control unit need to be within about $20 \mathrm{ft}$ of the application area, so the equipment needed to be staged close to the mandoor. In some applications, the hallway leading to the mandoor might be too small for the equipment.

Access to the work area was a problem for the oxygen tanks. The rest of the equipment was smaller and fairly easy to move. For any future applications, the maximum clearance under penstocks and the height of the air tanks need to be considered.

\section{One-year observations}

1. Nanosteel SHS 9172: Excellent condition with $\sim 0.5 \mathrm{sq}$ in. of missing coating and a slight depression in the substrate.

2. Vecalloy: $-4-5 \mathrm{sq}$ in. of bare substrate. Sharp edges indicate the coating broke off sharply as opposed to a wearing action. This is typical of an adhesion failure.

3. Ultimet: $\sim 5 \mathrm{sq}$ in. of bare substrate. Sharp edges indicate the coating broke off sharply as opposed to a wearing action. This is typical of an adhesion failure.

4. Stellite 6: Perfect condition. Several minor holes in substrate (reference Appendix A sketch) have not enlarged.

5. Praxair 1350 VM: About $75 \%$ of test area is bare substrate. Sharp edges indicate the coating broke off sharply as opposed to a wearing action. This is typical of an adhesion failure.

6. Amperit $588 \mathrm{Cr} 3 \mathrm{C} 2-\mathrm{NiCr} 75 / 25$ : There are bare areas including $\sim 2 \mathrm{sq}$ in. near the top of the test area, $\sim 0.5 \mathrm{sq}$ in. near the center of the area, and $\sim 2$ sq in. near the bottom of the area. Some of the edges are sharp while others are tapered. 
7. Amperit $584 \mathrm{Cr} 3 \mathrm{C} 2-\mathrm{NiCr} 75 / 25$ : There are bare areas including $1.5 \mathrm{sq}$ in. near the top of the test area and $\sim 4$ sq in. in the lower area of the test area. The tapered edges indicate the coating was worn through.

8. Stellite 21: There are bare areas including $\sim 2.5 \mathrm{sq}$ in. near the top of the test area and $\sim 5.5 \mathrm{sq}$ in. near the bottom of the area. Sharp edges indicate the coating broke off sharply as opposed to a wearing action. This is typical of an adhesion failure. There appear to be cracks, especially on what seem to be thicker areas.

9. Control 309 base material (for reference): An area of light roughness and a slight depression ( 1 sq in.) has developed due to cavitation. 


\section{Conclusions}

The level of surface preparation provided was considered standard by the contractor applying the coatings and is in the same general range as is required for several coating processes. The documentation provided by the contractor shows the typical surface profile to be 3.0-3.5 mils. In comparison, organic (paint) coatings as specified by the Unified Facilities Guide Specification (UFGS) 099702 require a surface profile of 1.5- 2.5 mils and UFGS 099701 requires a profile of 3- 4 mils for 85/ 15 zinc/aluminum metalized coatings thicker than 14 mils.

The HVOF application process was capable of applying all of the coatings selected for this evaluation equally well. There was very little visible smoke and the noise was similar to air-arcing, although slightly less. The process had similar ventilation requirements to welding, without the danger of arc flash, or need for ultraviolet light protection. Heat is not intense when outside of the flame tip. It does not require special shielding, nor does the gun cause damage when the tip of the flame is several feet from a surface.

The sample areas were chosen on the bottom of the runner because the J P5000 gun cannot reach the cavitation areas on the leading edge; the gun is too large and there is a minimum offset of approximately $18 \mathrm{in}$. The minimum offset would be a disadvantage for some smaller turbines where space is very restricted.

The feeder and control unit needed to be within about $20 \mathrm{ft}$ of the application area, so the equipment needed to be staged close to the mandoor. In some applications, the hallway leading to the mandoor might be too small for the equipment.

Access to the work area was a problem for the oxygen tanks. The rest of the equipment was smaller and fairly easy to move. For any future applications, the maximum clearance under penstocks and the height of the air tanks should be considered.

After 1 year, the uncoated control area had developed an area of roughness that included a slight depression due to cavitation. The cavitation area was easy to identify because of its dull appearance in contrast to the bright and 
shiny appearance of the remainder of the area. (All areas of applied test coatings were very dull, making it impossible to identify the beginnings of cavitation damage.) This control area was effective in documenting the level of cavitation damage that is experienced in this area of the buckets.

Of all the coatings applied, the Stellite 6 application appeared to be providing the best performance after 1 year; however, the Nanosteel was also very good. Many of the observed failures had sharp edges indicating coating adhesion failure rather than erosion as the chief mode of failure.

Small holes were documented in the test areas after the fill weld and grinding process. These small holes did not appear to increase the level of cavitation damage to the immediate area or be detrimental to the performance of any of the coatings applied.

After 1year, it is clear that many of the coatings have failed. Allowing these coatings to remain in place will have no adverse impact on the operation of the turbine. Two of the coatings appear to be virtually unchanged from the time of application and may be found to provide long-term resistance to damage caused by cavitation. It is recommended that all the coatings remain in place until the next regularly scheduled maintenance. At that time the performance should again be documented and compared to the uncoated control area. 


\section{References}

Boy, J effery H, Ashok Kumar, Patrick March, Paul Willis, and Herbert Herman. 1997. Cavitation- and Erosion-Resistant Thermal Spray Coatings. Technical report USACERL 97/ 118/ADA329272. Champaign, IL: US Army Construction Engineering Research Laboratory.

US Army Corps of Engineers (Civil Works). 2009. Unified Facilities Guide Specification (UFGS) 099701, Metallizing: Hydraulic Structures. Accessed at: http:// www.wbdg.org/ ccb/ DOD/ UFGS/ UFGS\%2009\%2097\%2001.00\%2010.pdf

US Army Corps of Engineers (Civil Works). 2009. UFGS 099702. Painting: Hydraulic Structures. Accessed at: http:// www.wbdg.org/ ccb/ DOD/UFGS/ UFGS\%2009\%2097\%2001.00\%2010.pdf 


\section{Appendix A: Hand Sketches of Test Areas}

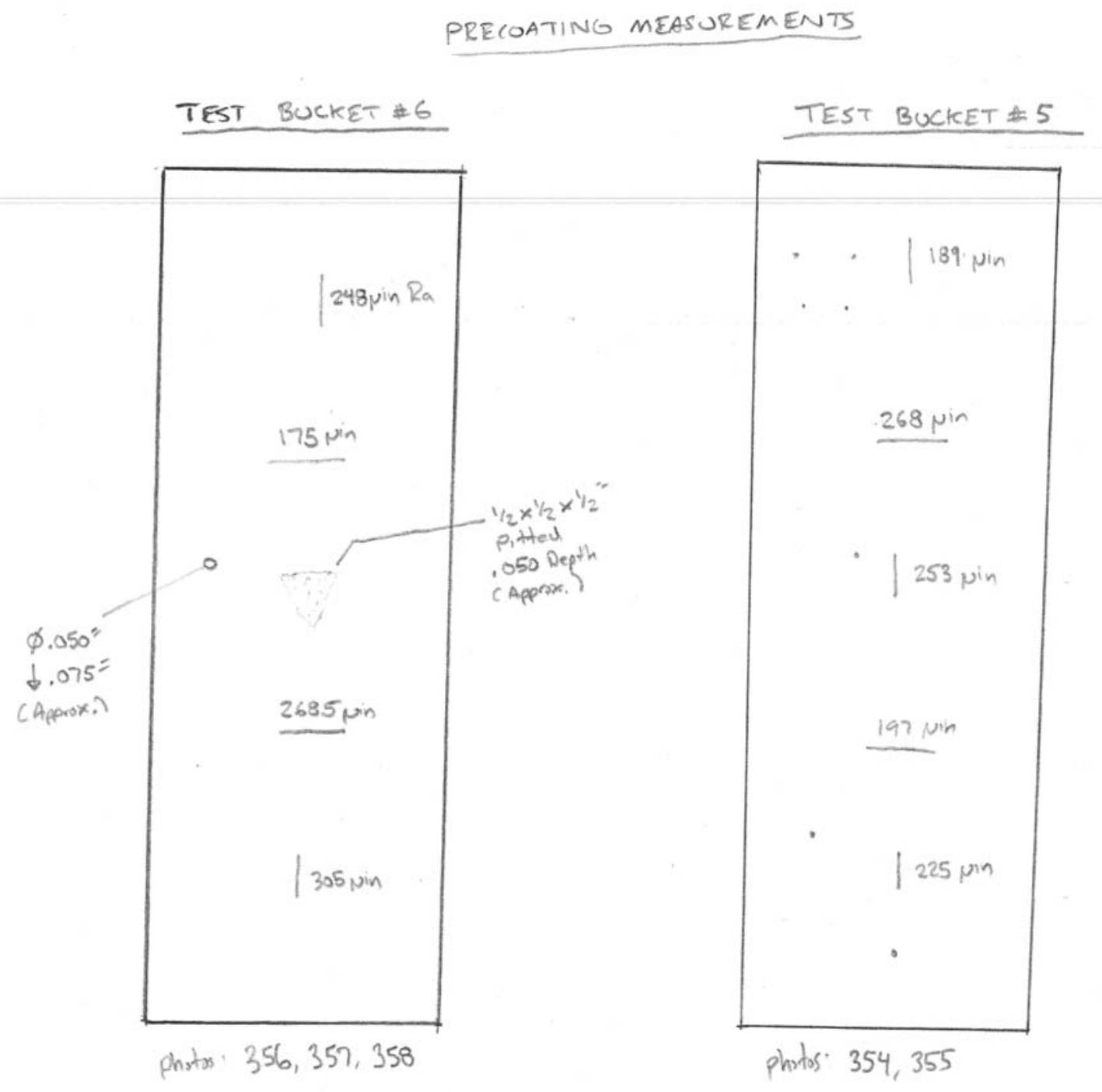


TEST BUCKET \#2

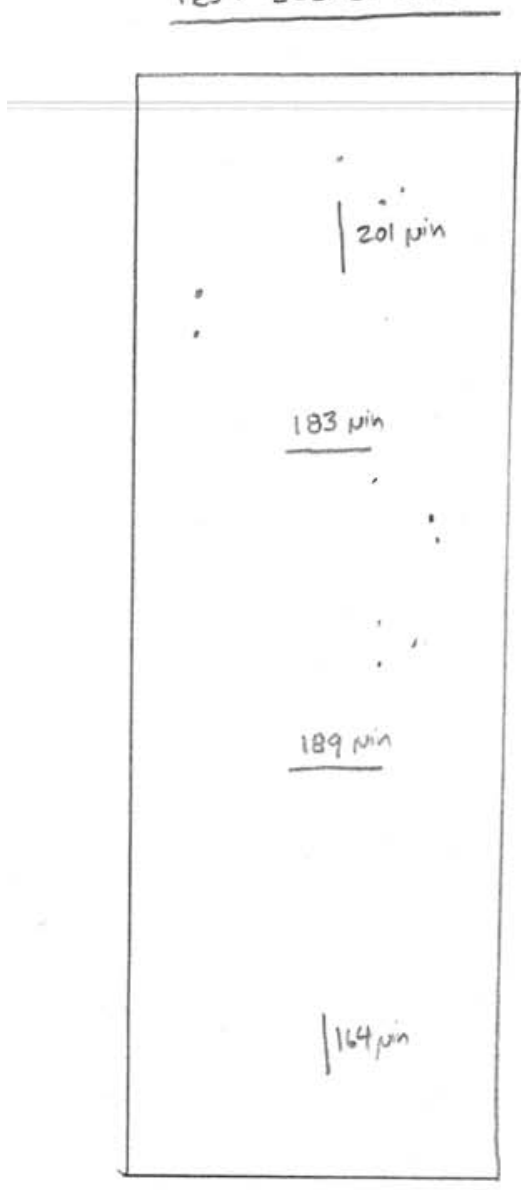

photos: 350,351

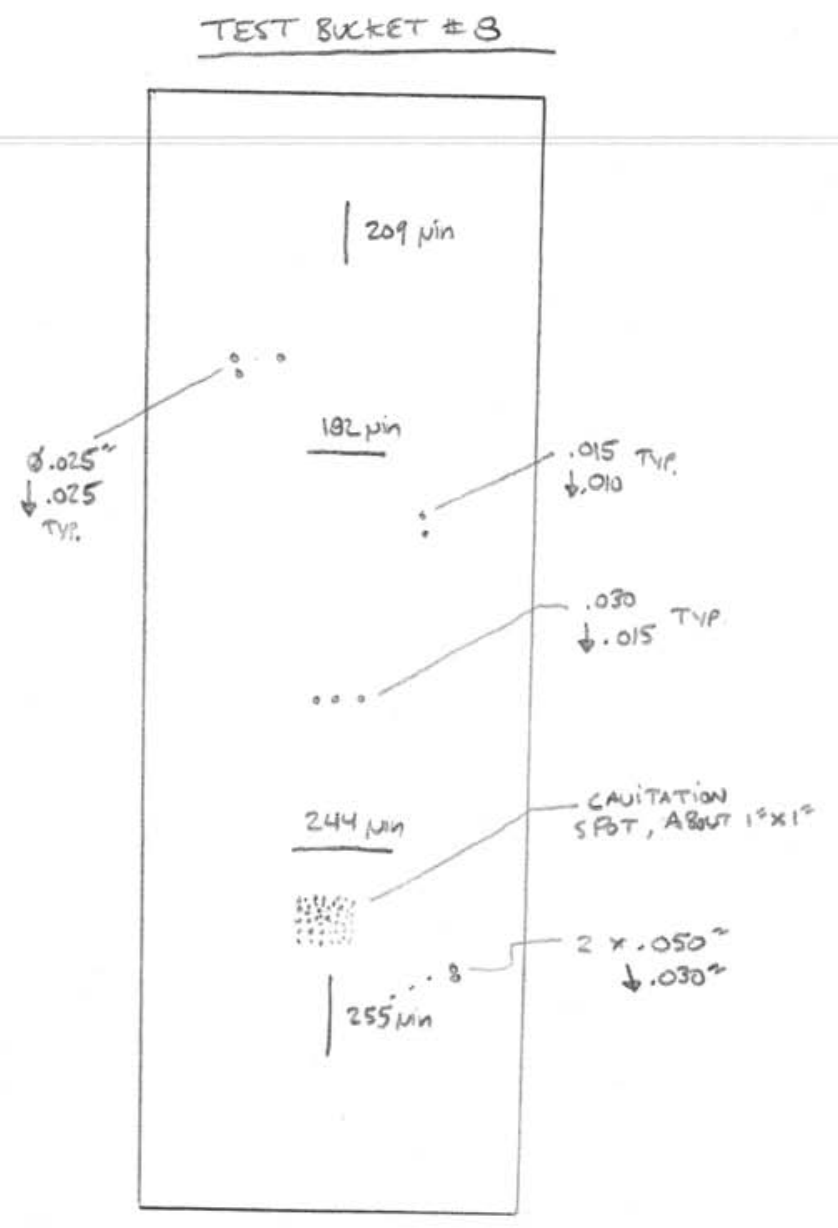




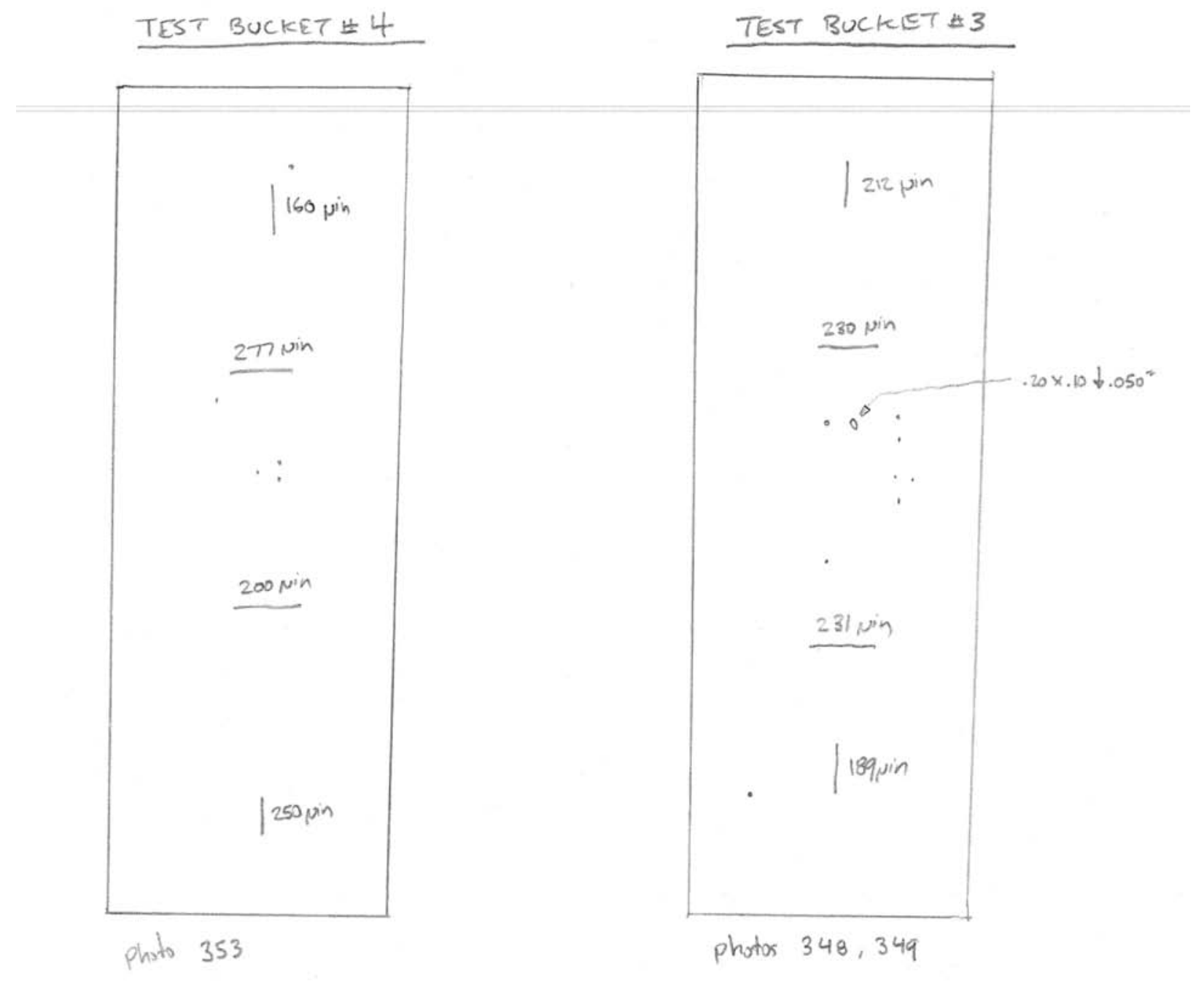




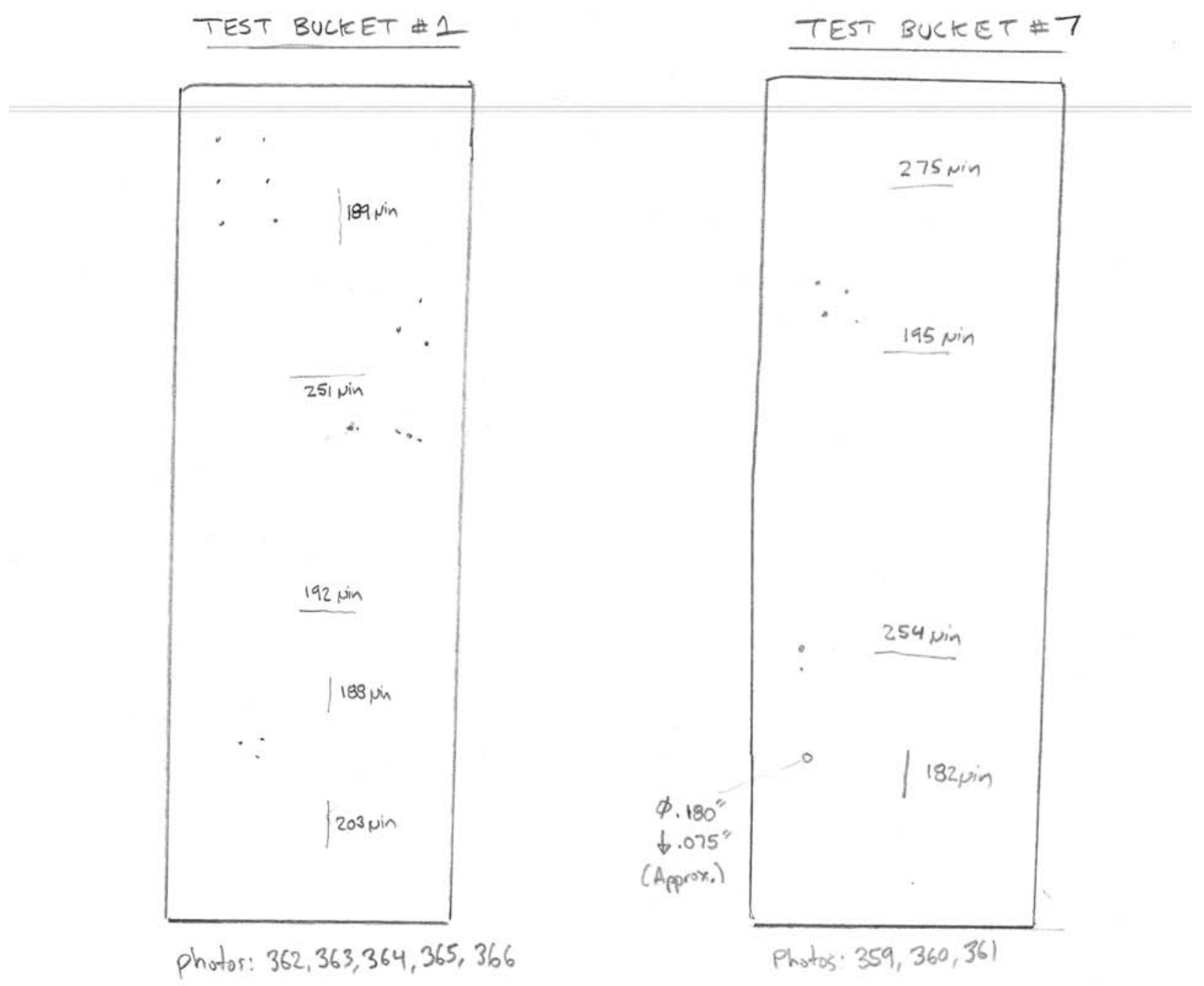


POST COATING SURFACE FINISH MEASUREMENTS
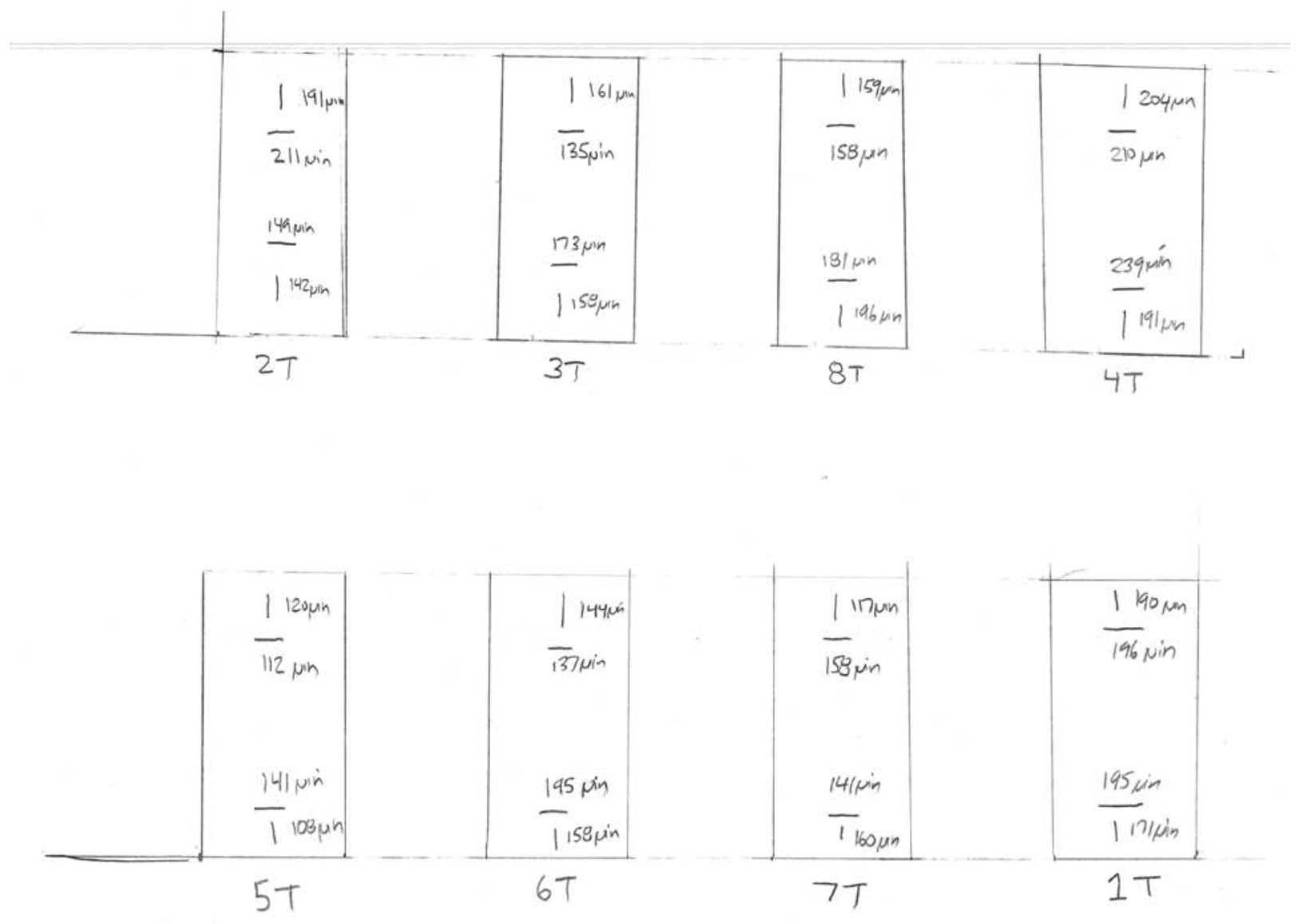


\section{Appendix B: Material Documentation and Application Equipment Settings}

\section{Materials tested}

MATERIALS

\begin{tabular}{|c|c|c|c|}
\hline MATERIAL & DESIGNATION & LOT \# & DESIGNATION \\
\hline NanoSteel & SHS 9172 HV1 & $08-50$ & 1T \\
\hline Vecalloy & Vecalloy & $07-227$ & 2T \\
\hline Deloro Stellite & Ultimet & $5090137-2$ & 3T \\
\hline Praxair & CO-106-1 (Stellite 6) & 46 & 4T \\
\hline Praxair & 1350 M & 418 & 5T \\
\hline H.C.Starck & Amperit 588.074 & 4100900 & 6T \\
\hline H.C.Starck & Amperit 584.1 & $\mathbf{4 2 2 0 8 4 0}$ & 7T \\
\hline Deloro Stellite & Stellite 21 & $\mathbf{5 0 9 0 1 3 6 - 2}$ & 8T \\
\hline
\end{tabular}




\section{Equipment used}

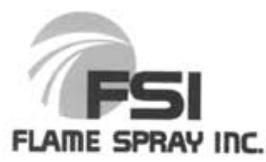

\section{EQUIPMENT \\ HVOF JP 5000 SYSTEM}

The TAFA JP-5000 uses an elegantly simple and effective design to produce High Pressure HVOF (HP/HVOF) coatings of incomparable quality. Coating benefits include:

- High and controllable coating density

- High and controllable coating hardness

- High bond strength (test adhesive fails before coating)

- Coating thickness exceeding $1 / 2^{\prime \prime}(12.7 \mathrm{~mm})$

- Smoother as-sprayed finish In addition to the outstanding coating quality, the JP-5000 delivers spray rates four times higher than typical HVOF systems.

\section{JP 5000 CONSOLE}

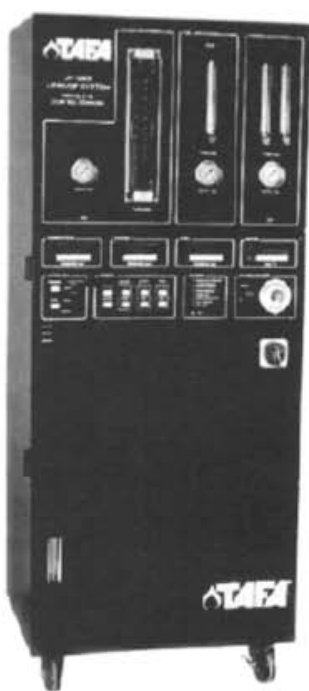

POWDER FEEDER

MODEL 5500
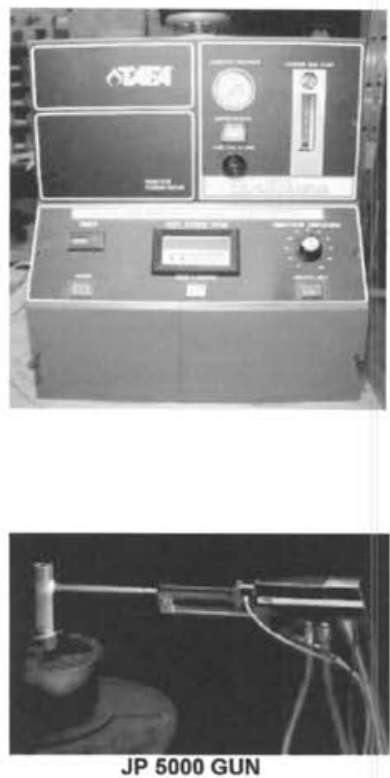


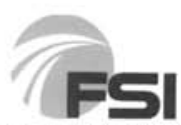

FLAIIE SPRAY INC.

\section{EQUIPMENT UTILIZED FOR COMPLIANCE WITH AMS 2447 JP 5000 HVOF THERMAL SPRAY SYSTEM DESCRIPTION.}

The primary component of this coating system is the JP 5000 gun. It is an internal combustion device. The combustion products are accelerated and exit the nozzle, producing a narrow jet of hot gas. Powder particles injected into the flame at the nozzle entrance are effectively heated and accelerated. When directed onto a target, they have sufficient thermal and kinetic energy to produce a dense, well-bonded coating.

The powder particles are introduced axially into the center of the exhaust jet. The powder particles melt or are softened from the heat and due to their high velocity, the particles when they hit a solid work piece are interlocked, resulting in a smooth coating that exhibits high bond strength, high density, and is usually very hard.

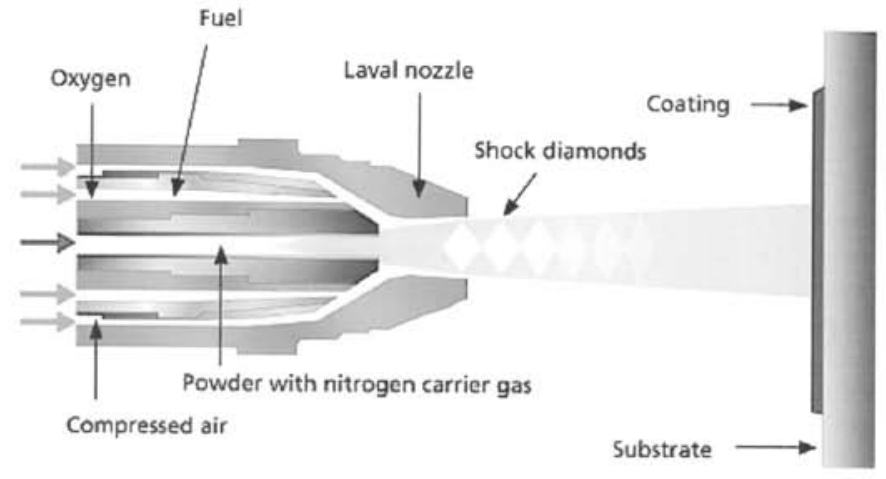




\section{Spray parameters}

17. TECHNICAL DATA BULLETIN 1.9.2.2SH-1350VM

$\begin{array}{llr}\text { JP-5000 HP/HVOF } & \text { File: } & 1.9 .2 .2 \mathrm{SH}-1350 \mathrm{VM} \\ \text { Issue: } & \text { M11002 } \\ \text { M10523 }\end{array}$

\section{Spray Parameters}

TAFA 1350VM Tungsten Carbide - 10 Cobalt - 4 Chromium

Although spray parameters vary, the following settings are recommended as good starting points for this coating. Some modifications may further enhance the coating quality.

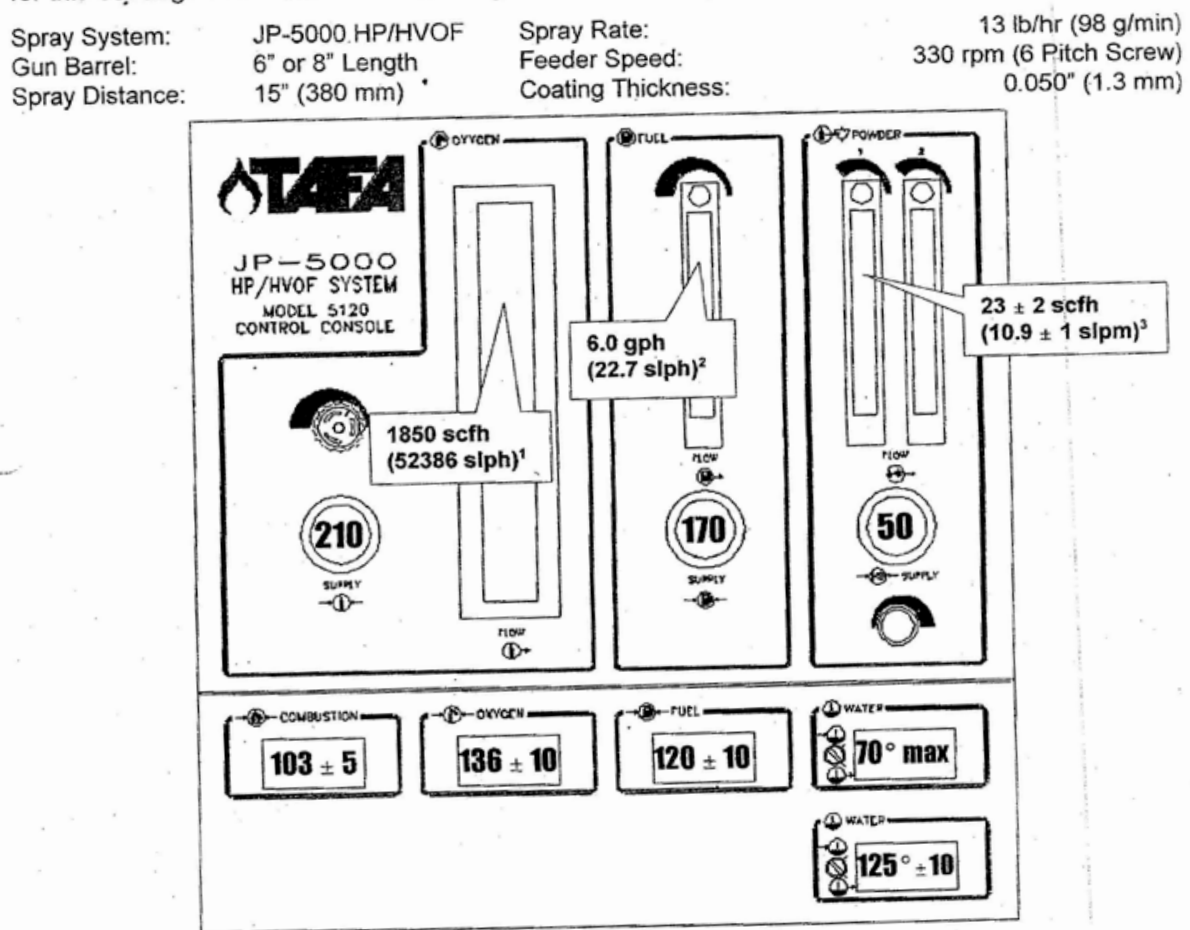

1. Oxygen Flow - The above flow setting is based on 210 psi supply pressure. For different supply pressures, use the 1. Oxygen Flow - The above flow setting is based on 210 psi supply pressure. For different sulect flow for scfh specified above. 2. Fuel Flow - Users of older control consoles with a 0 to $100 \%$ tube in the fuel flowmeter should consult TAFA for the

3. Carrect settings. 3. Carrier Flow - The needle valve on the console flowmeter. All flow rates are for nitrogen.

WA A WCORPORATED World Headquarters 146 Pembiole Road, Concord, NH 03301 USA $\operatorname{tax}+603225.4342$

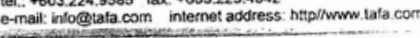

TAFA SOUTH AMERICA Sao Paulo - SP - Brasil CEP 04761-010 tel. +55 112475655 fax: $551152 \%$ 05. e-mali: div tata geutectic combr
TAFA EUROPE. LTD Burm Meadow Roa North Moons Moat, Redditch, WORCS, B98 9NZ, Englan tel: $+44(0) 1.527 .836 .700$ tax +44 (0) 

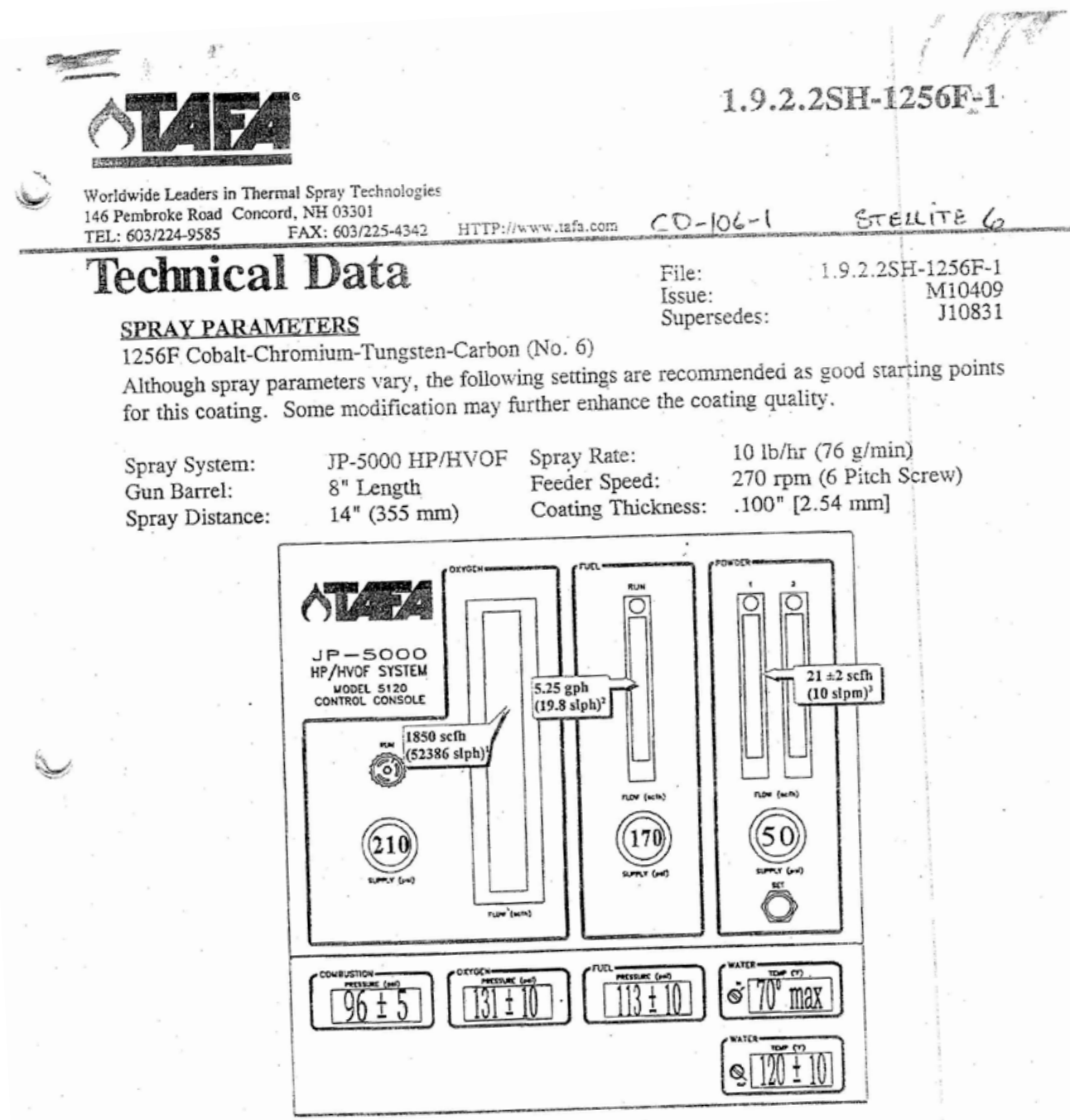

1.9.2.2SH $-1256 \mathrm{~F}-1$

Worldiwide Leaders in Thermal Spray Technologies

Technical Data

STELITE

SPRAY PARAMETERS

$1256 \mathrm{~F}$ Cobalt-Chromium-Tungsten-Carbon (Nettings are recommended as good starting points for this coating. Some modification may further enhance the coating quality.

$\begin{array}{llll}\text { Spray System: } & \text { JP-5000 HP/HVOF } & \text { Spray Rate: } & 10 \mathrm{lb} / \mathrm{hr}(76 \mathrm{~g} / \mathrm{min}) \\ \text { Gun Barrel: } & 8^{\prime \prime} \text { Length } & \text { Feeder Speed: } & 270 \mathrm{rpm}(6 \mathrm{Pitch} \text { Screw }) \\ \text { Spray Distance: } & 14^{\prime \prime}(355 \mathrm{~mm}) & \text { Coating Thickness: } & .100^{\mathrm{n}}[2.54 \mathrm{~mm}]\end{array}$
1. Oxygen Flow - The above fiow setting is based on 210 psi supply pressure. For different supply pressures, use the Pressure Correction Chart in the Operation Section of the Mate

2. Fuel Flow - Users of older control consoles with 20 to $100 \%$ tube in the fuel flowmeter should consult

3. TAFA for the correct settings. should be adjusted with the needle valve on the console nowmeter. All flow rates are for nitrogen.

Copyright ${ }^{\circ} 1996$ TAFA Incorporated, Concord, NH - USA. All rights reserved. 


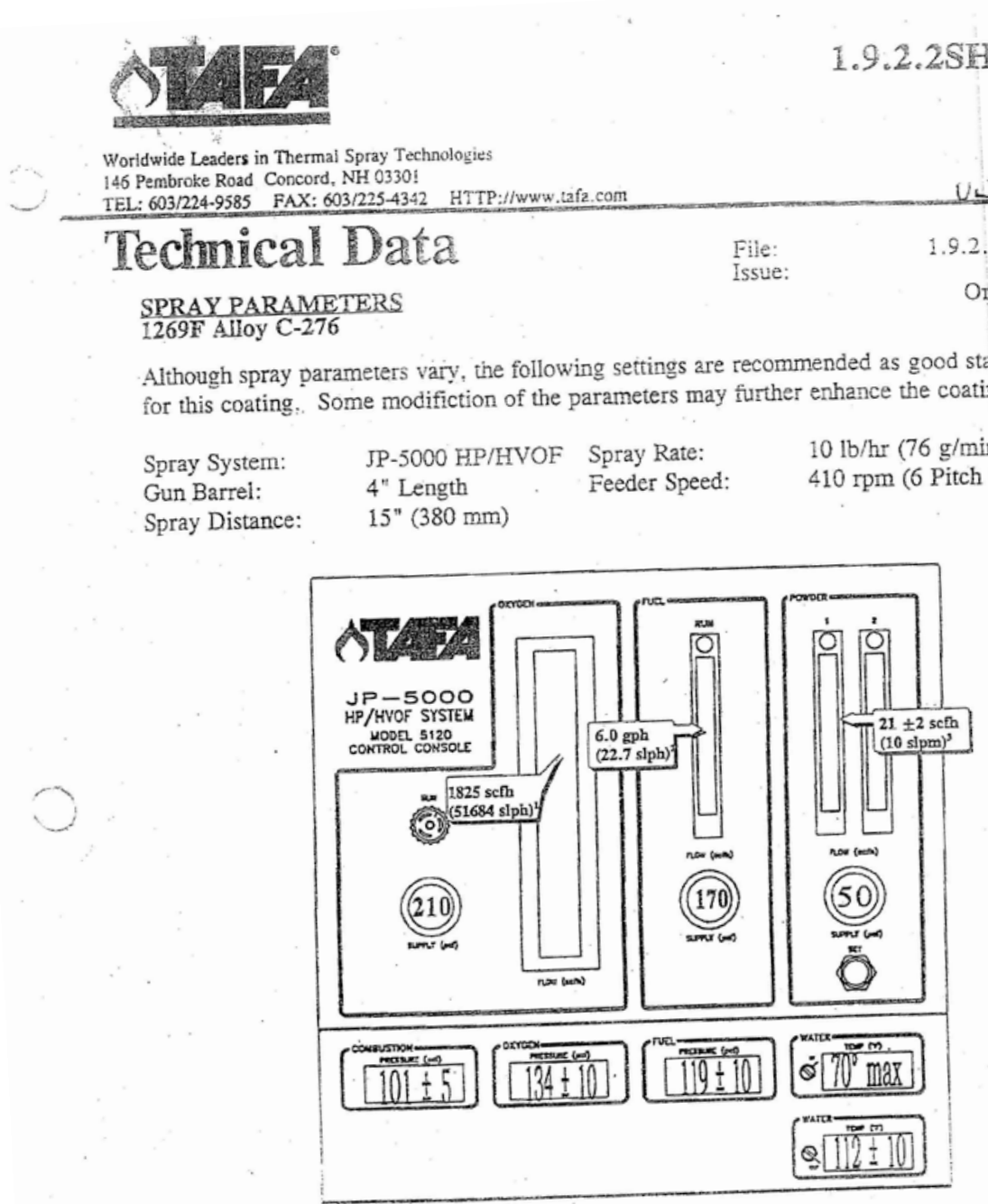

- Oxygen Flow - The above flow setting is based on 210 psi supply pressure. For different supply pressures, use the Pressure Correction Char in the Operation Section of the Manual to determine the correct flow for scfh specified above.

Fuel Flow - Users of older control consoles with a 0 to $100 \%$ vibe in the fuel flowmeter should consult

2. TAFA for the correct settings.
Carrier Flow - The needie vaive above the powder feeder flowmeier should be ieft wide open and the flow Carrier Flow - The neede valve above the powder reeder nlowmeter. All fiow tates are for nitrogen.

Copyright 1996 TAFA Incorporated, Concoru, NH - USA. All rights reserved. 


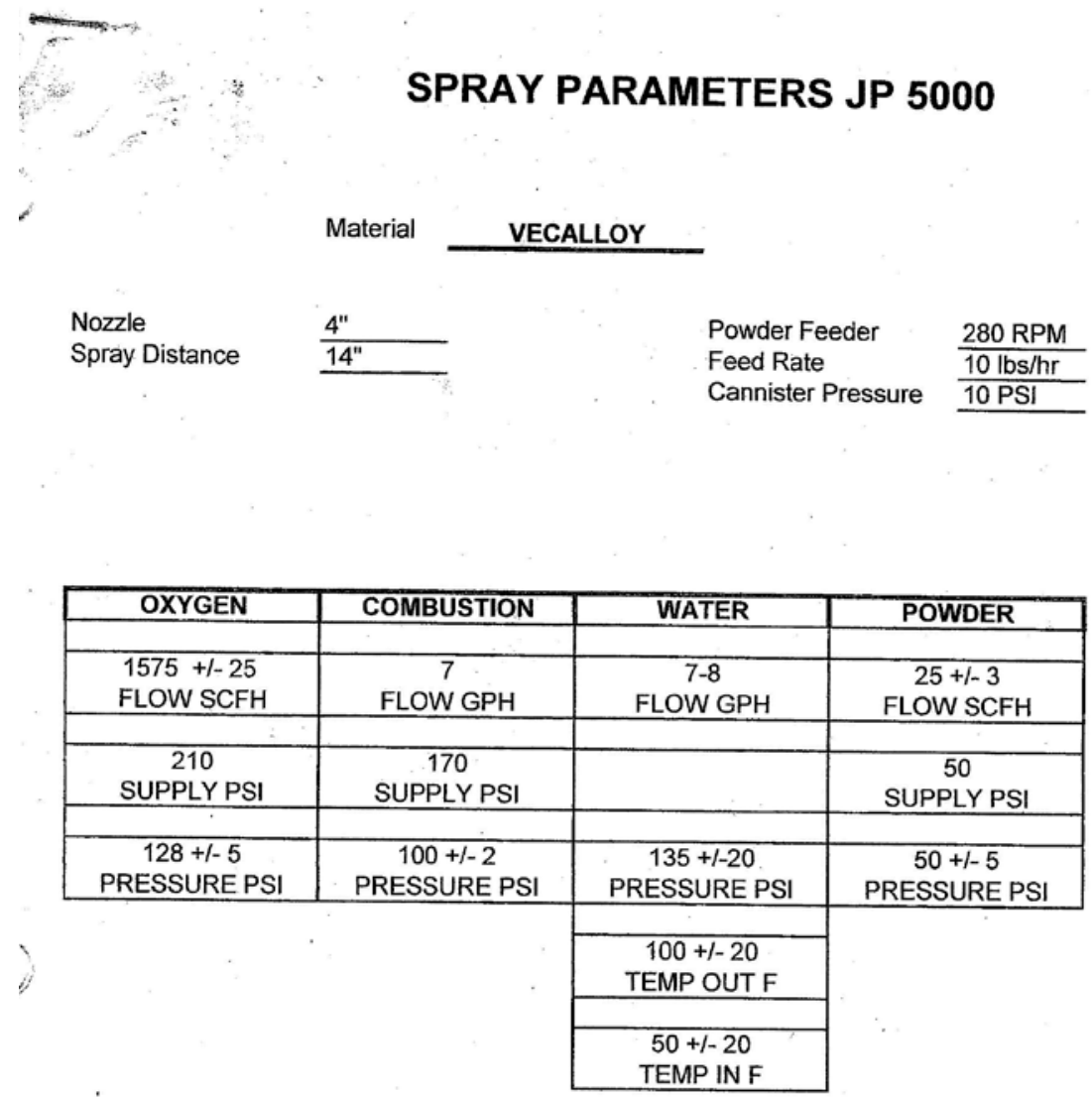




\section{TECHNICAL DATA BULLETIN}

$\underline{\text { JP-5000 HP/HVOF }}$

Spray Parameters Nanosteel SHS 9172

Although spray parameters vary, the following settings are recommended as good starting points for this coating. Some modification may further enhance the coating quality.

Spray System:

Gun Barrel:

JP-5000 HP/HVOF Spray Rate:

4" Length

Feeder Speed:

$10 \mathrm{lb} / \mathrm{hr}(76 \mathrm{~g} / \mathrm{min})$

Spray Distance:

$14 "(355 \mathrm{~mm})$

Coating Thickness:

$270 \mathrm{rpm}$ (6 Pitch Screw)

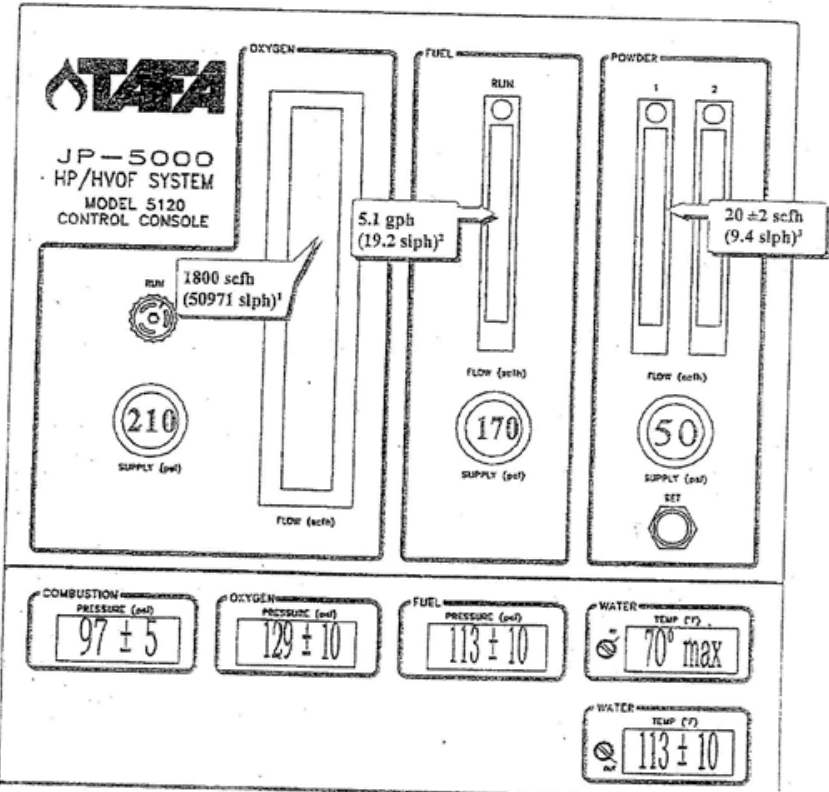

1. Oxygen Flow - The above fiow setting is based on 210 psi supply pressure. For different supply pressures. use the Pressure Correction Chart in the Operation Section of the losmul to determine the correct flow io scfh specified above.

Fuel Flow - Users of older control consoles with a 0 to $100 \%$ tube in the fuel fiowmeter should consul TAFA for the correct settings.

3. Carrier Flow - The needie valve above the powder feeder flowmeter should be iefi wide open and the fiou should be adjusted with the needie valve on the console flowmeter. All flow' rates are for nitrogen. 


\section{T. TECHNICAL DATA BULLETIN 1,9.2.2SH-1375VM $J P=5000 \mathrm{HP} / \mathrm{HVOF}$ \\ File: $19.22 \mathrm{SH}-1375 \mathrm{VM}$ \\ Issue: $\quad$ M10620 Supersedes: L10202 \\ Spray Parameters \\ TAFA 1375VM Chromium Carbide - 25 Nickel Chromium}

Aithough spray parameters vary, the following settings are recommended as good starting points for this coating. Some modifications may further enhance the coating quality.

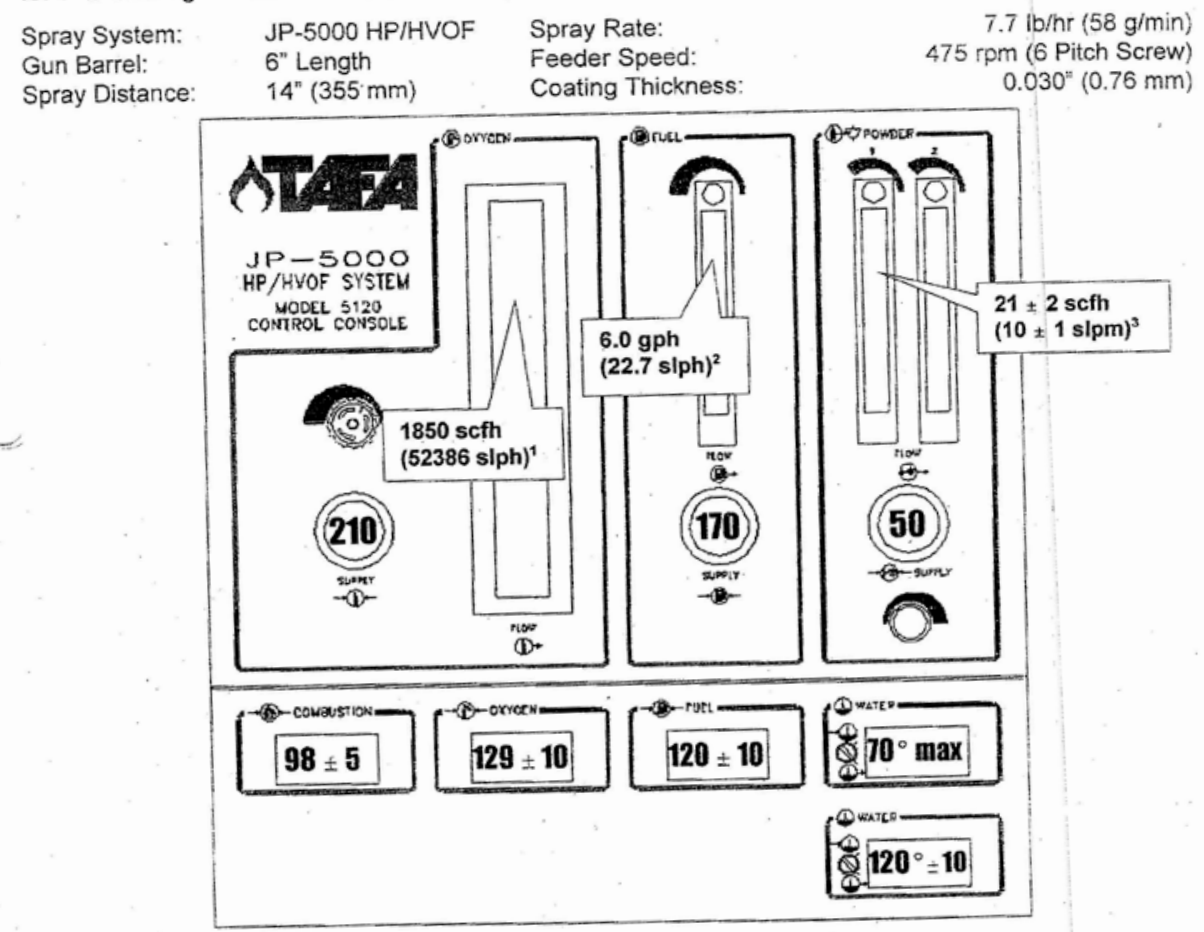

1. Oxygen Flow - The above flow setting is based on $210 \mathrm{psi}$ supply pressure. For different supply pressures, use the

Pressure Correction Chart in the Operation Section of the Manual to deternine the correct flow for scth specified above. 2. Fuel Flow - Users of older control consoles with a 0 to $100 \%$ tube in the fuel flowmeler should consult TAFA for the 2. 2 correct settings.

3. Carrier Flow. The needie valve above the powder feeder flowmeter shouid be left wide open and the fiow should be adjusted with the needle valve on the console flowmeter. All flow rates are for nitrogen. 
TECHNICALDATABULLETIN 19.2

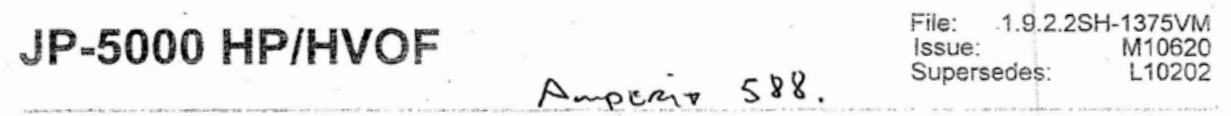

\section{Spray Parameters}

\section{TAFA 1375VM Chromium Carbide - 25 Nickel Chromium}

Although spray parameters vary, the following settings are recommended as 9000 starting points for this coating. Some modifications may further enhance the coating quality.

$\begin{array}{lllr}\text { Spray System: } & \text { JP-5000 HP/HVOF } & \text { Spray Rate: } & 7.7 \mathrm{lb} / \mathrm{hr}(58 \mathrm{~g} / \mathrm{min}) \\ \text { Gun Barrel: } & 6^{n} \text { Length } & \text { Feeder Speed: } & 475 \mathrm{rpm}(6 \mathrm{Pitch} \mathrm{Screw}) \\ \text { Spray Distance: } & 14^{n}(355 \mathrm{~mm}) & \text { Coating Thickness: } & 0.030^{n}(0.76 \mathrm{~mm})\end{array}$

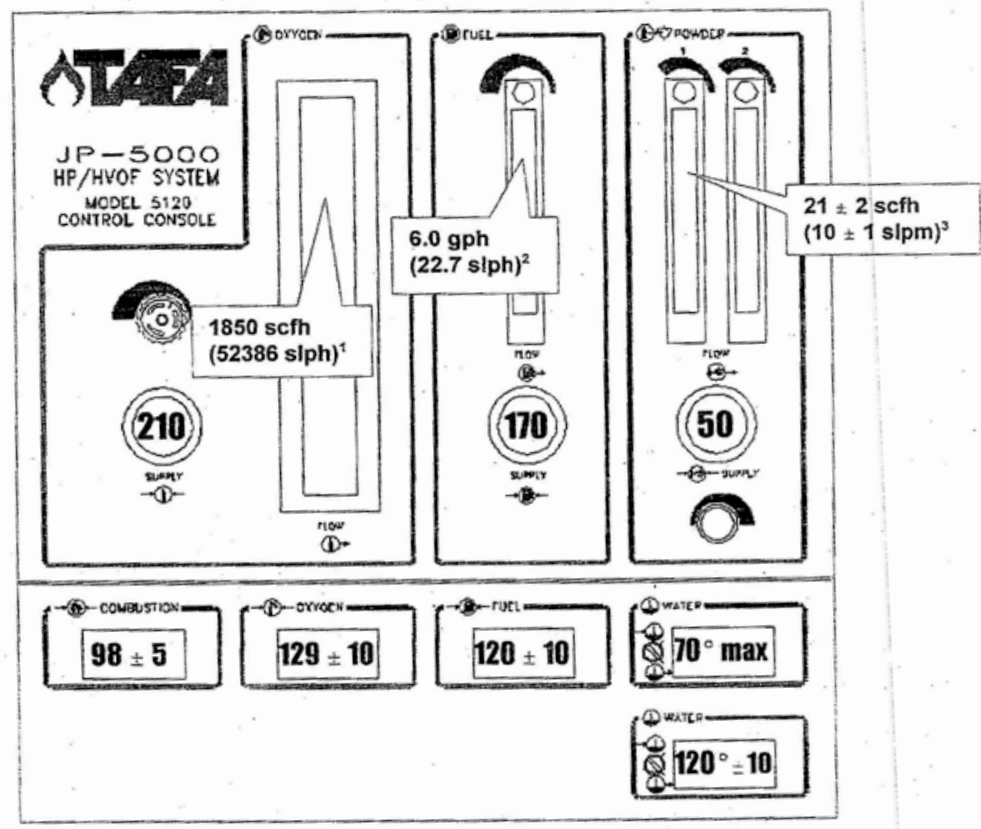

\footnotetext{
1. Oxygen Flow - The above fiow setting is based on 210 psi supply pressure. For different supply pressures, use the 1. Pressure Correction Chart in the Operation Section of the Manual to determine the correct flow for scfh specified above. 2. Fuel Flow - Users of older control consoles with a 0 to $100 \%$ tube in the fuel flowmeter should consult TAFA for the correct settings.

3. Carrier Flow - The needle valve above the powder feeder fiowmeter should be left wide open and the fiow should be adjusted with the needle valve on the console flowmeter. All flow rates are for nitrogen.$$
-
$$$$
\text { AFA INCORPORATED }
$$$$
\begin{aligned}
& \text { World Headquarters } \\
& 146 \text { Pembroke Road, Concord. NH 03sor USA }
\end{aligned}
$$ 


\section{Tensile testing}

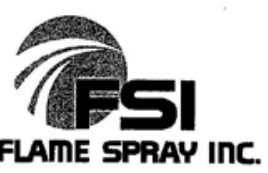

\section{SKETCHES OF TEST SAMPLES}

HVOF SYSTEM COATING

PER SPECIFICATION AMS 2447 and ASTM C- 633

TENSILE BARS:

SAMPLE DIMENSIONS:
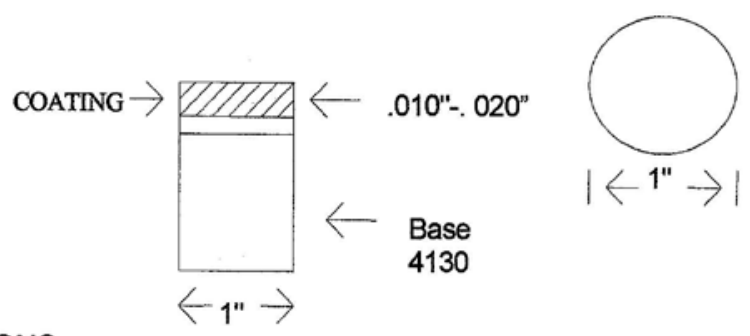

\begin{tabular}{|c|r|r|r|}
\hline \multirow{2}{*}{ SERIAL NUMBER } & \multicolumn{3}{|c|}{ DIMENSION } \\
\hline & PRESPRAY & POST SPRAY & THICKNESS \\
\hline $1 T-1$ & 2.202 & 2.222 & 0.020 \\
\hline $1 T-2$ & 2.187 & 2.212 & 0.025 \\
\hline $1 T-3$ & 2.190 & 2.203 & 0.013 \\
\hline $2 T-1$ & 2.198 & 2.212 & 0.014 \\
\hline $2 T-2$ & 2.185 & 2.203 & 0.018 \\
\hline $2 T-3$ & 2.200 & 2.210 & 0.010 \\
\hline $3 T-1$ & 2.190 & 2.205 & 0.015 \\
\hline $3 T-2$ & 2.157 & 2.172 & 0.015 \\
\hline $3 T-3$ & 2.188 & 2.204 & 0.016 \\
\hline $4 T-1$ & 2.184 & 2.199 & 0.015 \\
\hline $4 T-2$ & 2.194 & 2.210 & 0.016 \\
\hline $4 T-3$ & 2.172 & 2.186 & 0.014 \\
\hline $5 T-1$ & 2.160 & 2.174 & 0.014 \\
\hline $5 T-2$ & 2.154 & 2.168 & 0.014 \\
\hline $5 T-3$ & 2.166 & 2.180 & 0.014 \\
\hline $6 T-1$ & 2.200 & 2.211 & 0.011 \\
\hline $6 T-2$ & 2.183 & 2.194 & 0.011 \\
\hline $6 T-3$ & 2.186 & 2.197 & 0.011 \\
\hline $7 T-1$ & 2.187 & 2.199 & 0.012 \\
\hline $7 T-2$ & 2.162 & 2.174 & 0.012 \\
\hline $7 T-3$ & 2.195 & 2.206 & 0.011 \\
\hline $8 T-1$ & 2.166 & 2.178 & 0.012 \\
\hline $8 T-2$ & 2.168 & 2.180 & 0.012 \\
\hline $8 T-3$ & 2.173 & 2.184 & 0.011 \\
\hline
\end{tabular}

Average PSI :

1T 10399, 2T 8610, 3T 10346, 4T 9212, 5T 9818, 6T 10341, 7T 10123, and 8T 7976.

See report on following pages. 


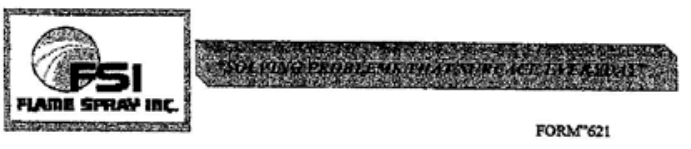

\section{AMS 2447 - Tensile Test Report}

Nov 25, 2009
Test Date 25-Nov-09 Testing Machine STM-100KN
Customer Name US Army Green River Dam Operator Ricky T.
Material Top Coat Nano Steel 9172 SHS
Wo Number $188681 \mathrm{~T}$
Lab Techniclan Ricky Loe

Report No. 1467

Purchase Order W9127N-10-Q-

Qty of Samples 3

Materlal Lot \# 08-050

Load Cell SIN (TVI104868), Unito (Lb3) 22480 Preload Value (Lbs) 50

Crosshead Speed ( Inches / $\mathrm{min}$ ) or Rate 0.05

Displacement Sensor XHD_100 (XHD100)

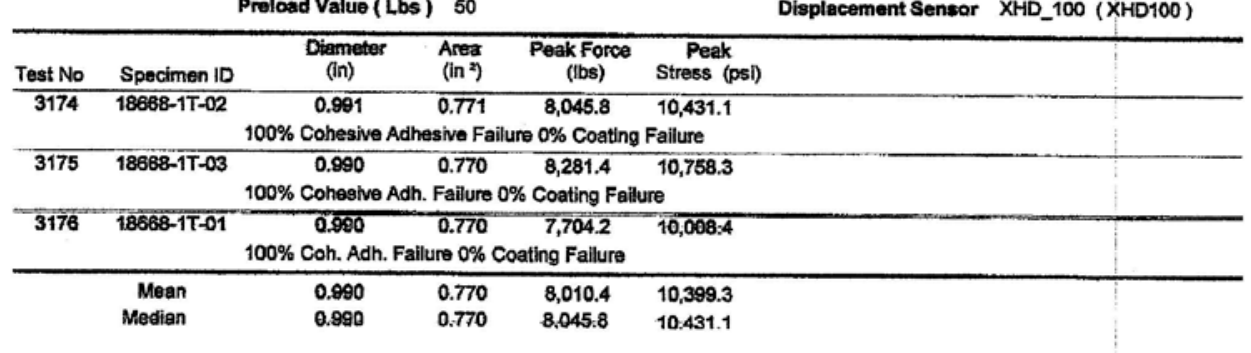




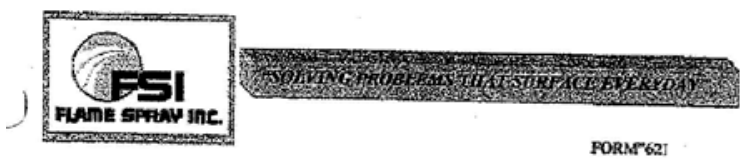

FORMr6:

AMS 2447 - Tensile Test Report

Nov 25, 2009

Test Date 25-Nov-08 Testing Machine STM-100KN

Customer Name US Army Green River Dam

Operator Ricky $\mathbf{T}$.

Material Top Coat Vecalloy

WO Number $186682 \mathrm{~T}$

Lab Technician Ricky Lee

Report No. 1468

Load Cell S/N (TVI104868), Units (Lbs ) 22480

Preload Value (Lbs) 50

Crosshead Speed (Inches / min ) or Rate 0.05

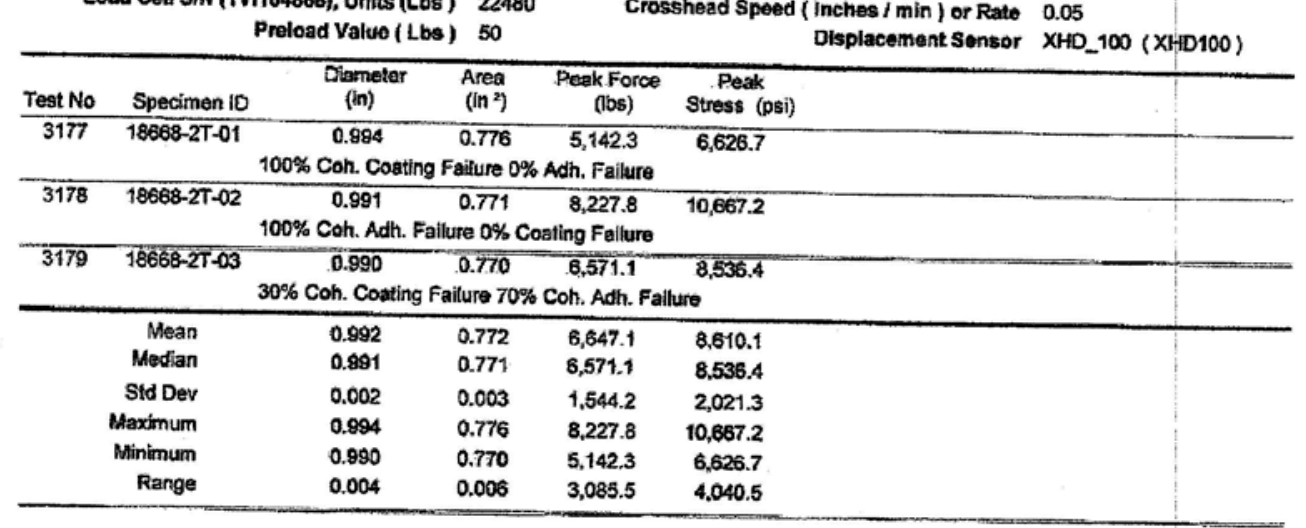

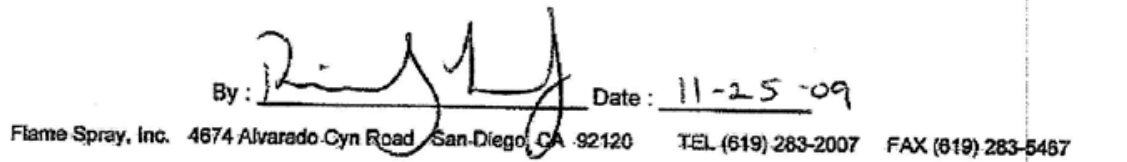




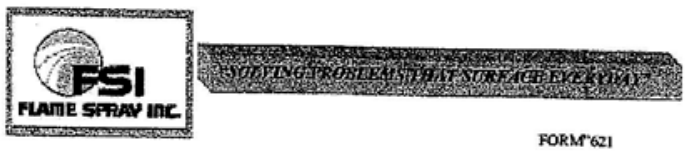

FORMPGI

AMS 2447 - Tenslle Test Report

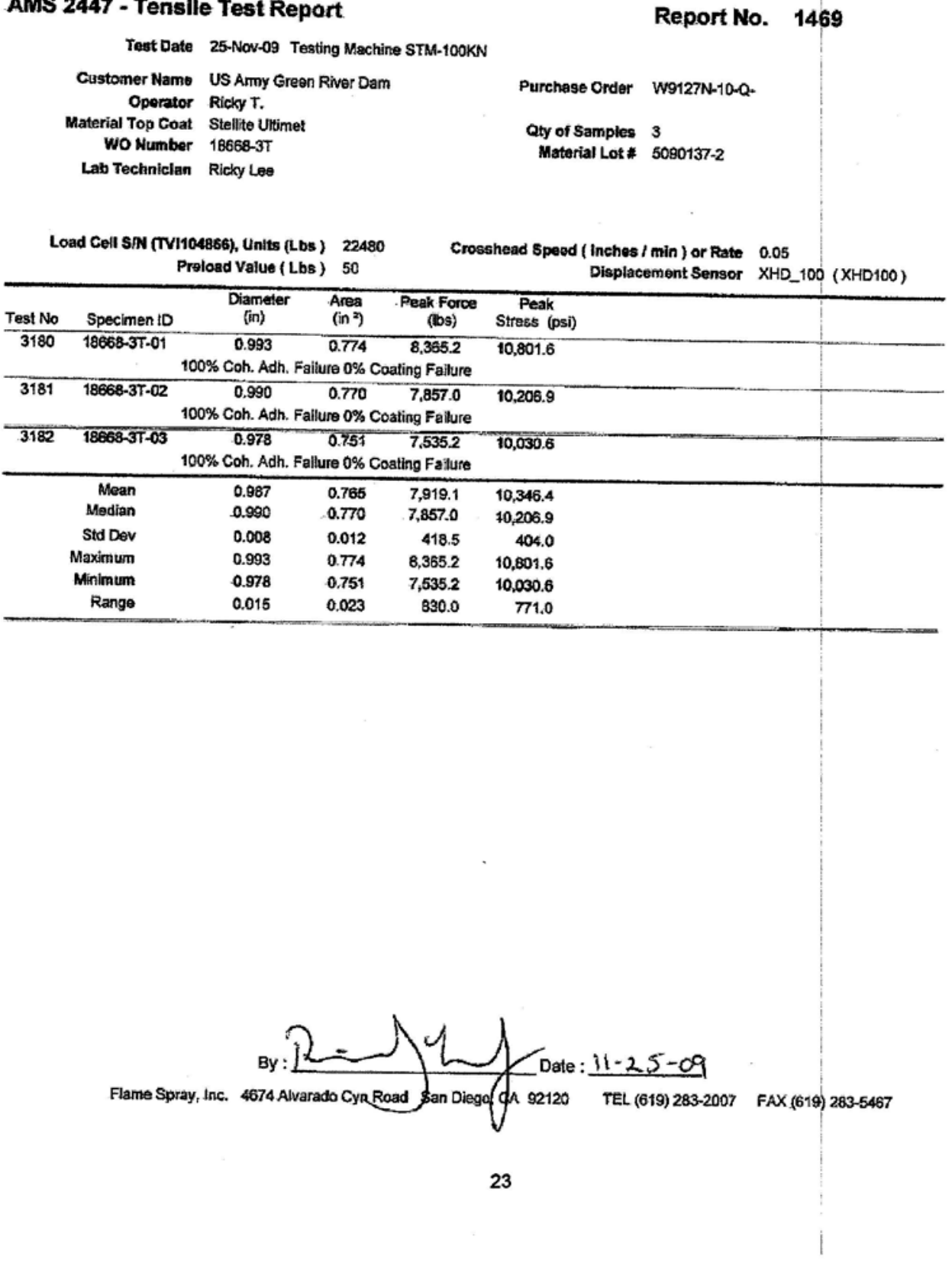

Nov 25, 2009

Report No. 1469

Customer Name US Army Green River Dam

aty of Samples 3

Material Lot * 5090137-2

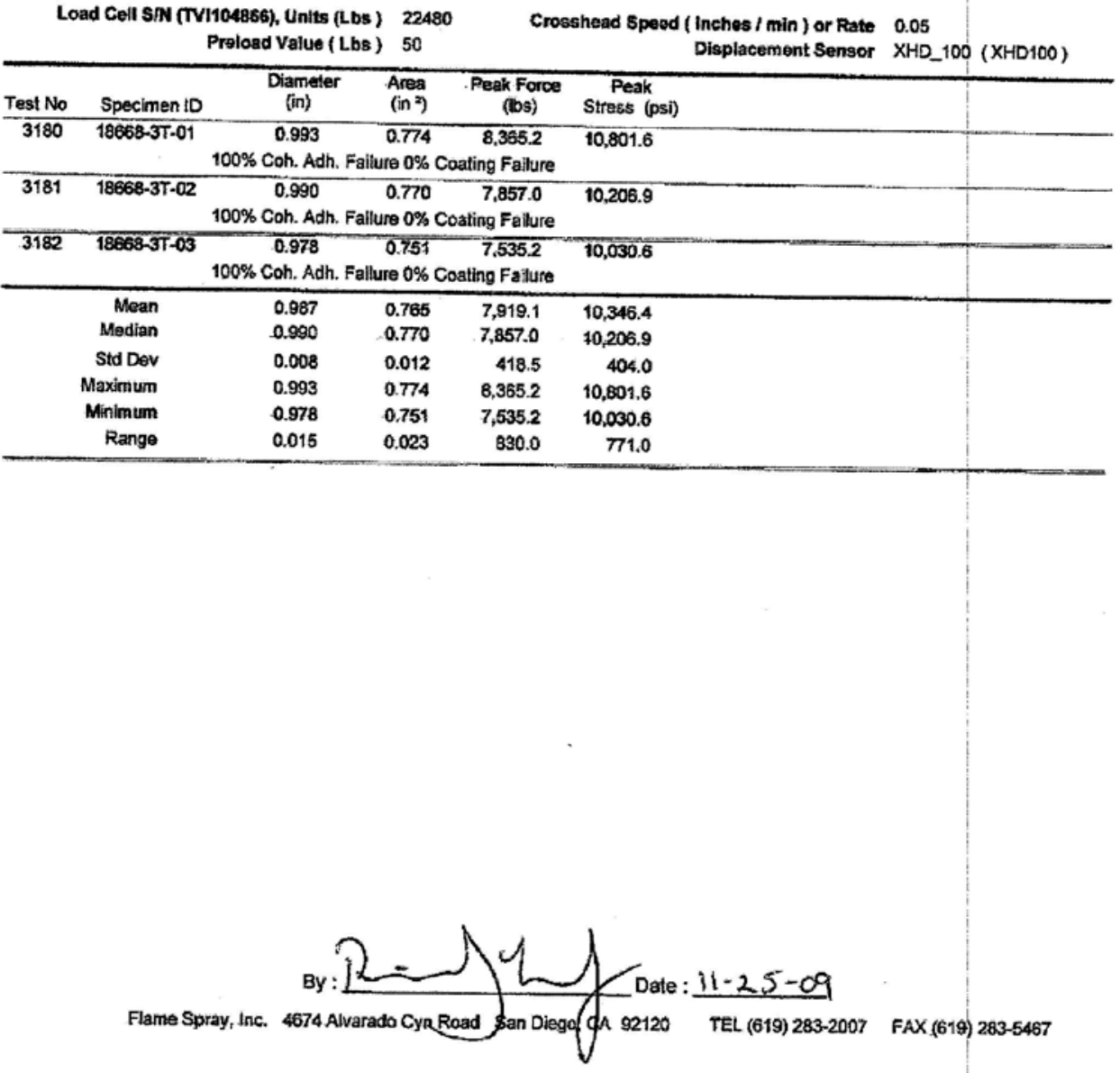




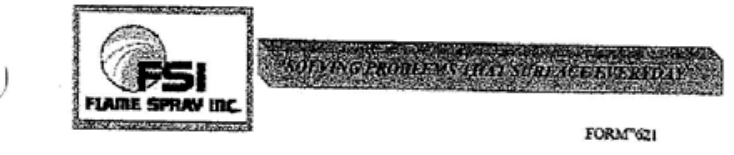

AMS 2447 - Tensile Test Report

Nov 25, 2009
Test Date 25-Nov-09 Testing Machine STM-100KN
Customer Name US Army Green River Dam Operator Ricky T.
Materiat Top Coat Stelfite 6
wo Number 18668
Lab Technician Ricky Lee

Report No. 1470

Load Cell SIN (TVI104866), Units (Lbs) 22480 Proload Value (Lbs) 50

Crosshead Speed ( Inches / $\mathrm{mln}$ ) or Rate 0.05

Purchase Order W9127N-10-Q

Qty of Samples 3

Material Lot \# 46

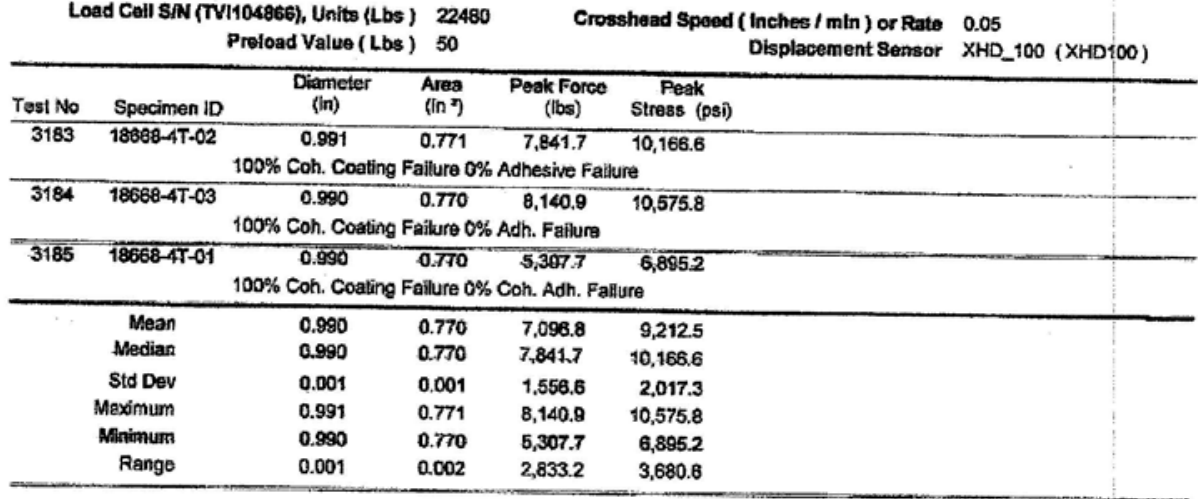

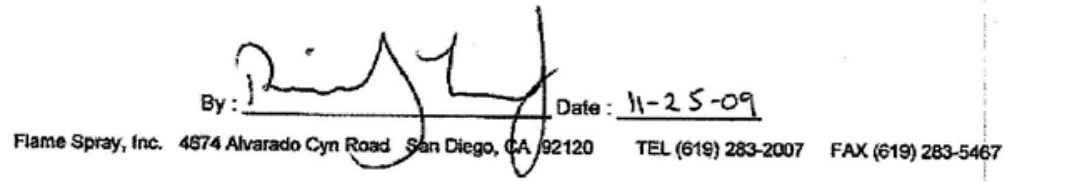




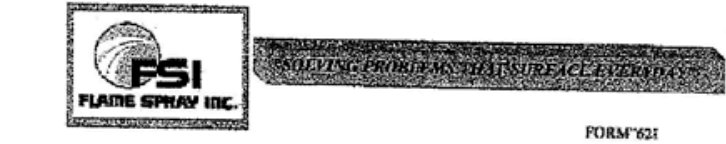

AMS 2447 - Tensile Test Report

Nov 25, 2009

A Test Date

Report No. 1471

Customer Name US Army Green River Dam

Operator Ricky $T$.

Material Top Coat Praxair 1350 VM

WO Number 18668-5T

Lab Technician Ricky Lee

Qty of Samples 3

Material Lot \# 418

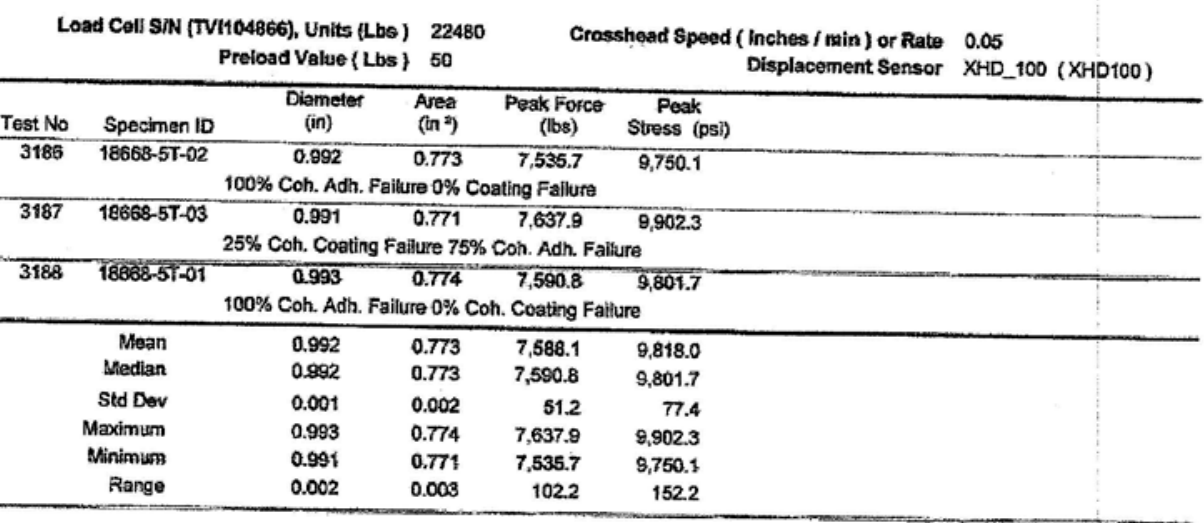

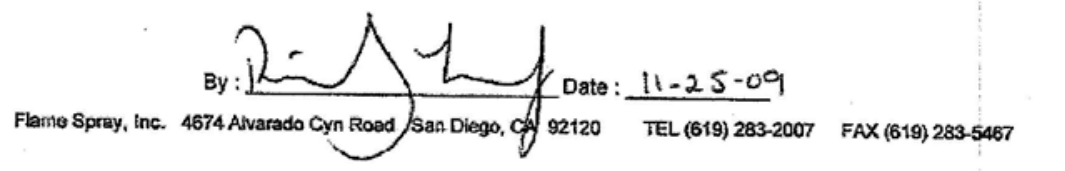




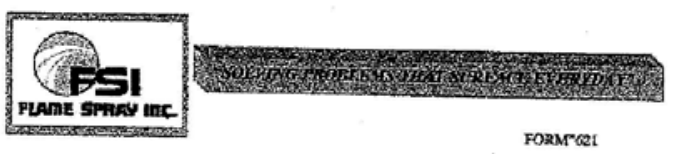

Nov 25, 2009

\section{AMS 2447 - Tensile Test Report}

Report No. 1472

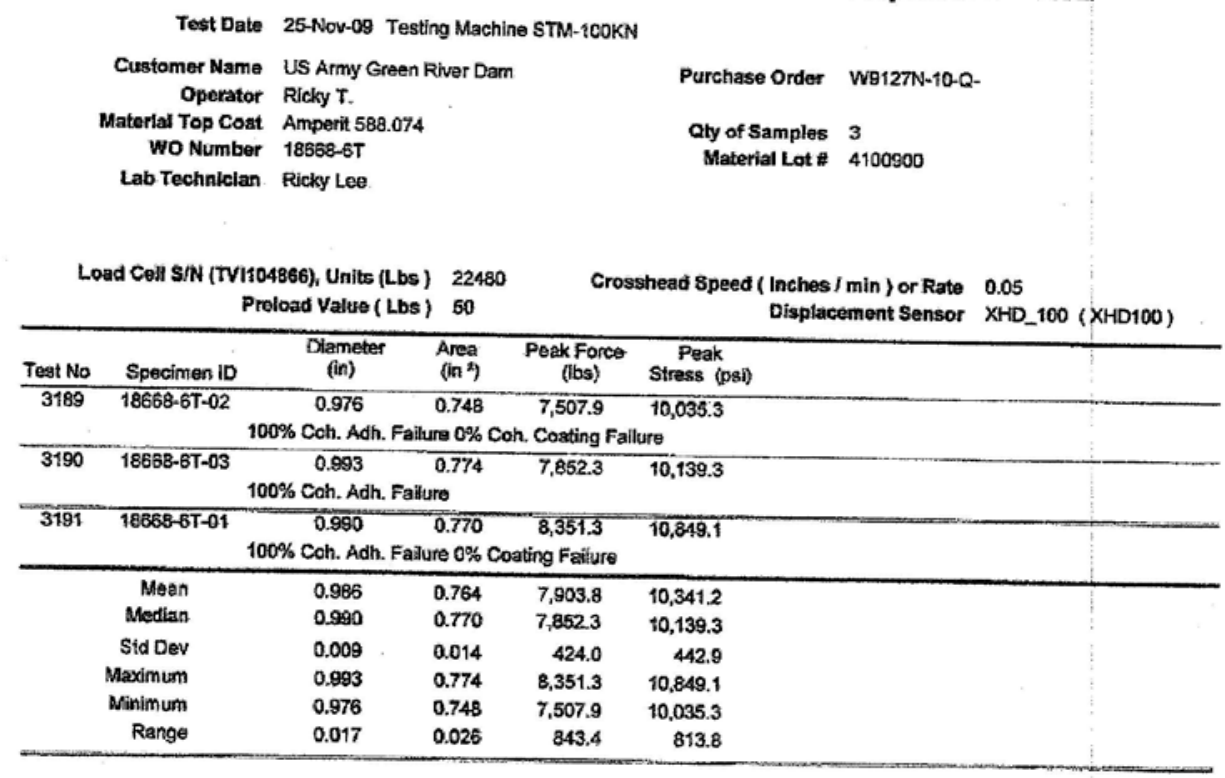

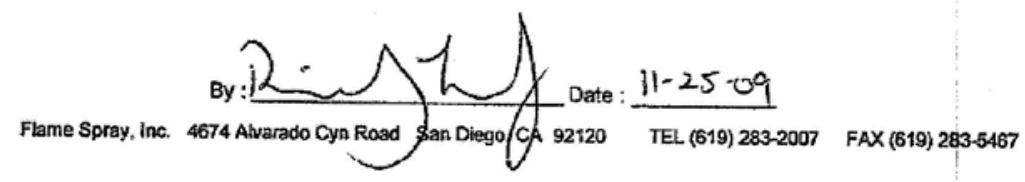




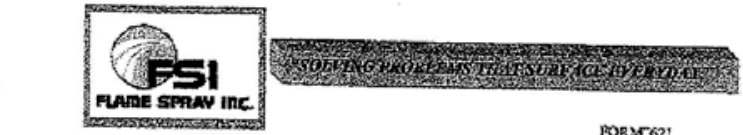

Forse21

Nov 25, 2009
Report No. $\quad 1473$

AMS 2447 - Tensile Test Report

Nov 25, 2009
Report No. 1473

Test Date 25-Nov-09 Testing Machine STM-100KN

Customer Narne US Army Green River Dam

Operator Ricky $T$.

Material Top Coat Amperit 584.1

wo Number 18668-7T

Lab-Technician Ricky Lee Preload Value (Lbs) 50

Crosshead Speed ( Inches / $\mathrm{min}$ ) or Rate 0.05

Purchase Order W9127N-10-Q.

Qty of Samples 3

Material Lot \# 4220840

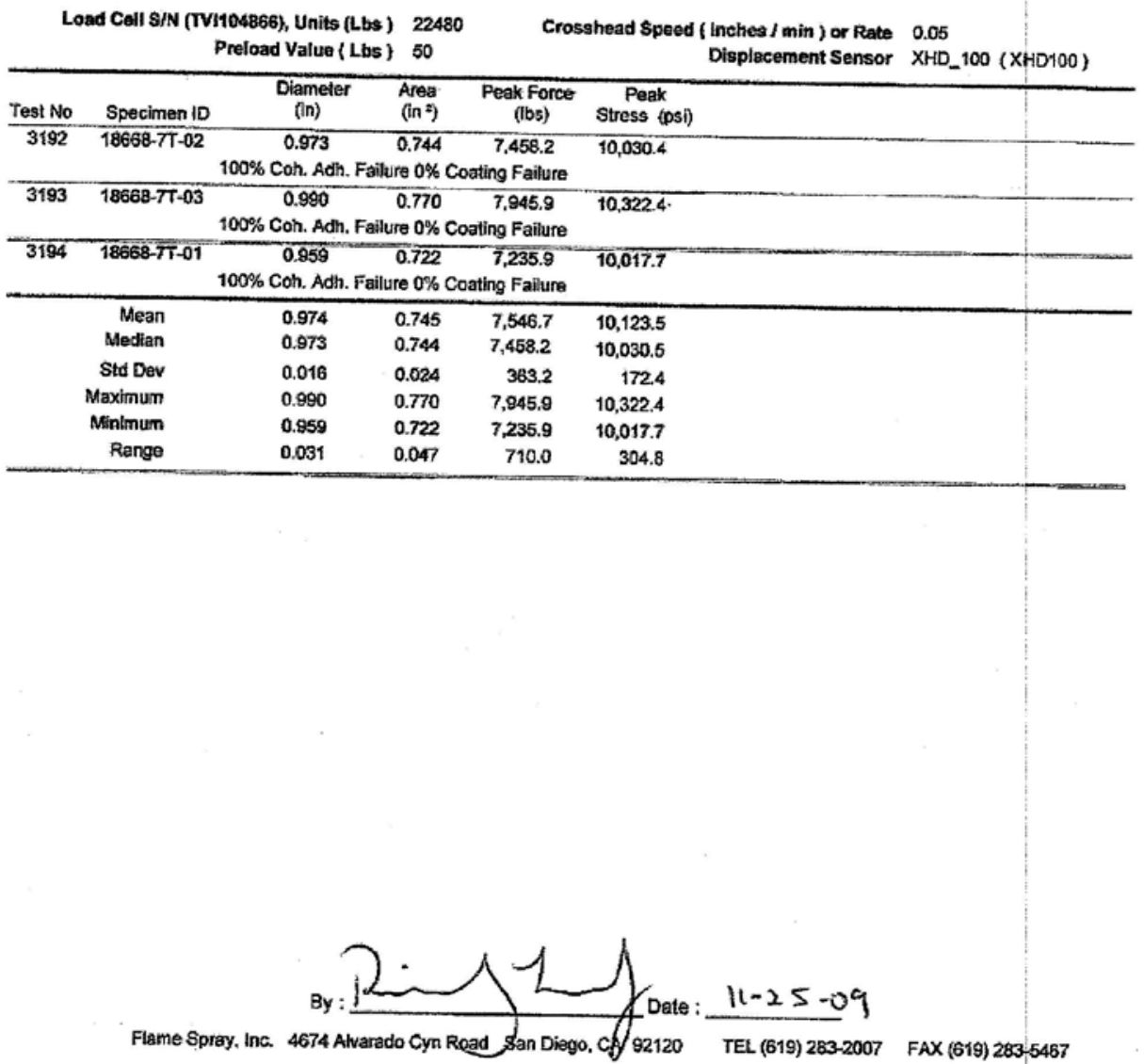




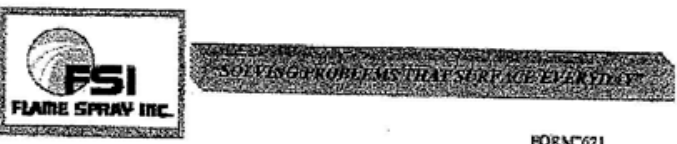

Nov 25, 2009

AMS 2447 - Tensile Test Report

Report No. 1474

Test Date 25-Nov-09 Testing Machine STM-100KN

Customer Name US Amy Green River Dam Operator Ricky.T.

Material Top Coat Stelite 21

Wo Number 18668-8T

Lab Technician Ricky. Lee

$\begin{aligned} & \text { Report No. } 1474 \\ \text { Purchase Order } & \text { Wo127N-10-Q- } \\ \text { Qty of Samples } & 3 \\ \text { Material Lot \# } & 5090136-2\end{aligned}$

Load Cell S/N (TVI104866), Units fLbs ) 22480 Preload Value (Lbs) 50

Crosshead Speed \{ Inches / $\mathrm{min}$ ) or Rate 0.05

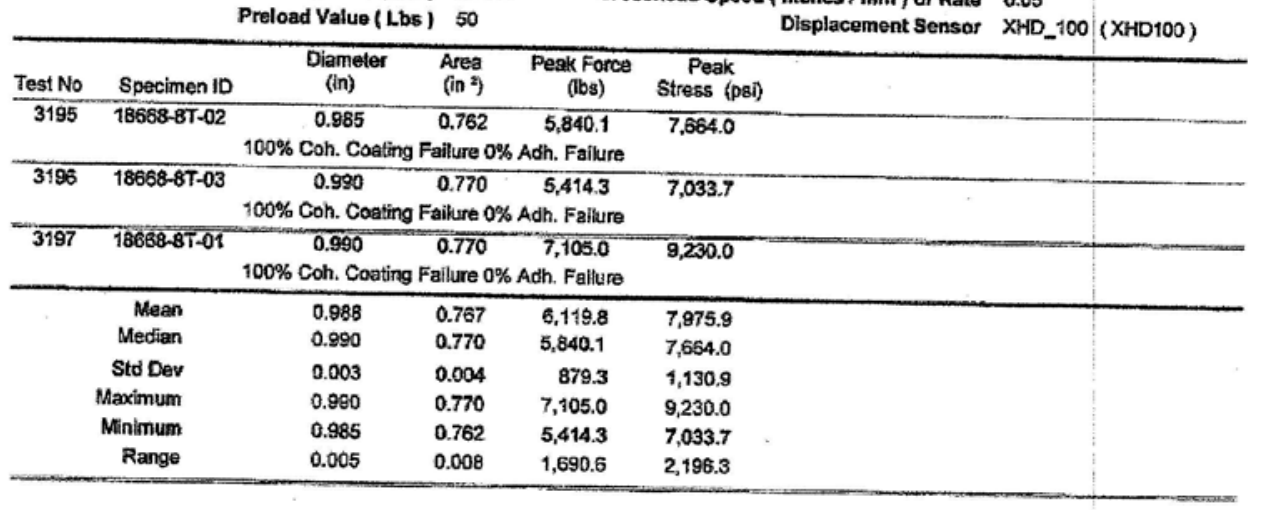

Flame Spray, inc. 4674 Alvaradocyn Rodd San Diego. CA 92120 TEL (619) 283-2007 FAX (619) 283-5467 


\section{Microstructure and hardness}

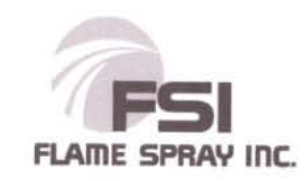

HVOF SYSTEM COATING

PER SPECIFICATION AMS 2447

TEST PANELS: (for Metallographic Examination including micro hardness)
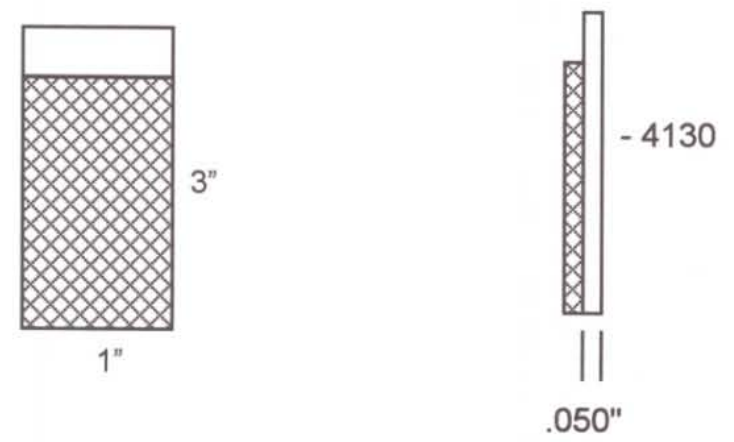

SAMPLE DIMENSIONS:

\begin{tabular}{|c|r|r|r|}
\hline \multirow{2}{*}{ SERIAL NUMBER } & \multicolumn{3}{|c|}{ DIMENSION } \\
\cline { 2 - 4 } & PRESPRAY & POST SPRAY & THICKNESS \\
\hline M1T & 0.051 & 0.070 & 0.019 \\
\hline M2T & 0.051 & 0.071 & 0.020 \\
\hline M3T & 0.050 & 0.072 & 0.022 \\
\hline M4T & 0.051 & 0.070 & 0.019 \\
\hline M5T & 0.051 & 0.068 & 0.017 \\
\hline M6T & 0.051 & 0.058 & 0.010 \\
\hline M7T & 0.051 & 0.059 & 0.011 \\
\hline M8T & 0.051 & 0.069 & 0.018 \\
\hline
\end{tabular}

Results were acceptable as shown in the Metallographic and Hardness report s in the following 


\begin{tabular}{|c|c|l|}
\hline Fume SFrAY inc. & $\begin{array}{c}\text { Quality Control } \\
\text { Microstructure }\end{array}$ & $\begin{array}{l}\text { Flame Spray Inc. } \\
\mathbf{4 6 7 4} \text { Alvarado Canyon } \\
\text { Rd. } \\
\text { San Diego, CA 92120 } \\
\text { Examination Report } \\
\text { 619-283-2007 }\end{array}$ \\
\hline
\end{tabular}

\begin{tabular}{|c|c|c|c|c|c|c|c|c|}
\hline \multicolumn{2}{|c|}{ Work Order \#: } & \multicolumn{2}{|c|}{18668} & \multicolumn{2}{|c|}{$\begin{array}{l}\text { Application } \\
\text { Spec: }\end{array}$} & \multicolumn{3}{|c|}{ AMS 2447} \\
\hline \multicolumn{2}{|c|}{$\begin{array}{c}\text { Purchase Order } \\
\# \text { : }\end{array}$} & \multicolumn{2}{|c|}{ W9127N-10-Q-0002 } & \multicolumn{2}{|c|}{ Lab. Technician: } & \multicolumn{3}{|c|}{ Ricky Lee } \\
\hline \multicolumn{2}{|c|}{ Customer: } & \multicolumn{2}{|c|}{$\begin{array}{l}\text { U.S. Army Green } \\
\text { River Dam Project }\end{array}$} & \multicolumn{2}{|c|}{ Objective: } & \multicolumn{3}{|c|}{$200 \mathrm{X}$} \\
\hline \multicolumn{2}{|c|}{ Material: } & \multicolumn{2}{|c|}{$\begin{array}{c}\text { Nano Steel } 9172 \\
\text { SHS } \\
\text { Lot \# 08-050 }\end{array}$} & \multicolumn{2}{|c|}{ Applicator: } & \multicolumn{3}{|c|}{ Ricky T. } \\
\hline \multicolumn{2}{|c|}{ Date: } & $11 / 23$ & & Sample Ni & nber: & & 1T-E & \\
\hline \multicolumn{9}{|c|}{ Acceptance Criteria } \\
\hline $\begin{array}{l}\text { Cracks } \\
\text { (None) }\end{array}$ & NONE & $\begin{array}{l}\text { Porosity } \\
\text { Max 2\% }\end{array}$ & $0.66 \%$ & $\begin{array}{c}\text { Interface } \\
\text { Contaminatio } \\
n \\
n \text { Nelam. } \\
\text { No Delam. }\end{array}$ & \multicolumn{2}{|c|}{$\begin{array}{c}\text { Acceptabl } \\
e \\
\text { No Delam. }\end{array}$} & $\begin{array}{l}\text { Oxide } \\
\text { Max } \\
1 \% \_\end{array}$ & $0.62 \%$ \\
\hline \multicolumn{2}{|c|}{$\begin{array}{l}\text { Unmelted Particles } \\
\text { Max } 0.01 \%\end{array}$} & \multicolumn{2}{|c|}{ Acceptable } & ive Particles & & \multicolumn{3}{|c|}{ Acceptable } \\
\hline
\end{tabular}

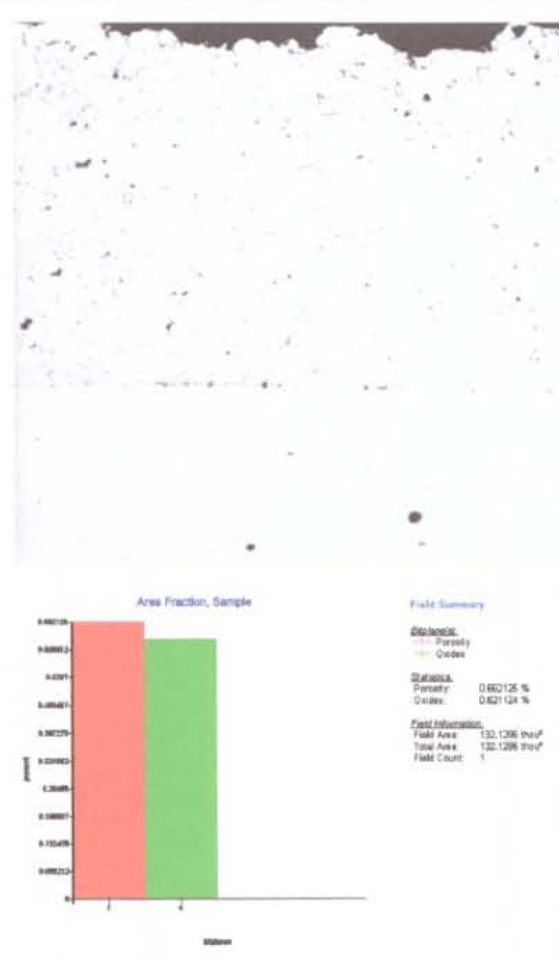




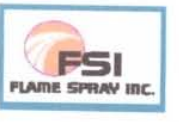

Test Performed

Date:

Lab W/O\#

Sample Number

P.O#

Customer

Application Spec.

Acceptance Criteria

Total \# of

Measurements
FLAME SPRAY, INC.

4674 Alvarado Canyon Rd.

San Diego, CA. 92120

\begin{tabular}{|c|c|c|c|c|}
\hline No & D1 & D2 & Avg D & HV \\
\hline 1 & 34.21 & 35.02 & 34.62 & 464.30 \\
\hline 2 & 35.82 & 36.72 & 36.27 & 422.89 \\
\hline 3 & 35.09 & 37.21 & 36.15 & 425.70 \\
\hline 4 & 32.92 & 34.72 & 33.82 & 486.38 \\
\hline 5 & 34.69 & 35.76 & 35.23 & 448.36 \\
\hline 6 & 32.33 & 32.86 & 32.60 & 523.63 \\
\hline 7 & 31.76 & 32.53 & 32.15 & 538.39 \\
\hline 8 & 35.82 & 36.4 & 36.11 & 426.65 \\
\hline 9 & 33.6 & 34.66 & 34.13 & 477.59 \\
\hline 10 & 34.97 & 34.96 & 34.97 & 455.05 \\
\hline AVG & & & & 466.89 \\
\hline
\end{tabular}

Laboratory Technician: 1

Hardness Test-Vicker Profile

$11 / 24 / 2009$

18668

18668-8T-A

W9127N-10-Q-0002

U.S. Army Green River D:

AMS 2447

400 Min Avg.

10 


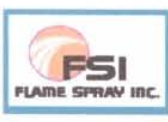

Test Performed

Date:

Lab w/O\#

Sample Number

P.O\#

Customer

Application Spec.

Acceptance Criteria

Total \# of

Measurements
FLAME SPRAY, INC.

4674 Alvarado Canyon Rd.

San Diego, CA. 92120
Hardness Test-Vicker Profile

$11 / 24 / 2009$

$\underline{18668}$

18668-1T-B

W9127N-10-Q-0002

U.S. Army Green River D:

AMS 2447

375 Min Avg.

10

\begin{tabular}{|c|c|c|c|c|}
\hline No & D1 & D2 & Avg D & HV \\
\hline 1 & 25.77 & 25.6 & 25.69 & 843.27 \\
\hline 2 & 26.24 & 27.42 & 26.83 & 772.83 \\
\hline 3 & 27.73 & 27.55 & 27.64 & 728.20 \\
\hline 4 & 25.92 & 26.72 & 26.32 & 803.07 \\
\hline 5 & 25.42 & 25.72 & 25.57 & 850.87 \\
\hline 6 & 25.28 & 25.5 & 25.39 & 862.98 \\
\hline 7 & 24.38 & 26.04 & 25.21 & 875.34 \\
\hline 8 & 27.57 & 26.79 & 27.18 & 753.05 \\
\hline 9 & 27.01 & 27.44 & 27.23 & 750.57 \\
\hline 10 & 25.87 & 27.51 & 26.69 & 780.96 \\
\hline AVG & & & & 802.11 \\
\hline
\end{tabular}

Laboratory Technician: 


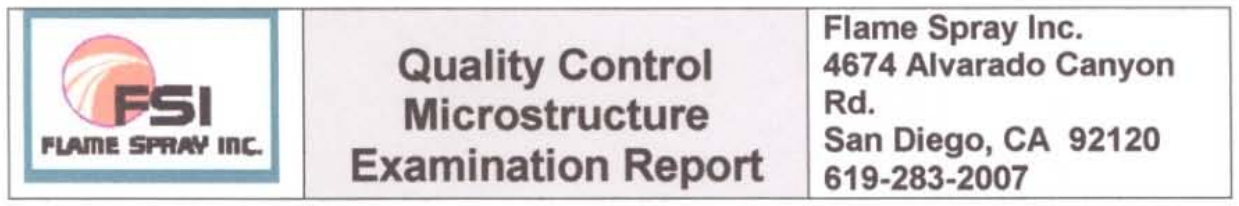

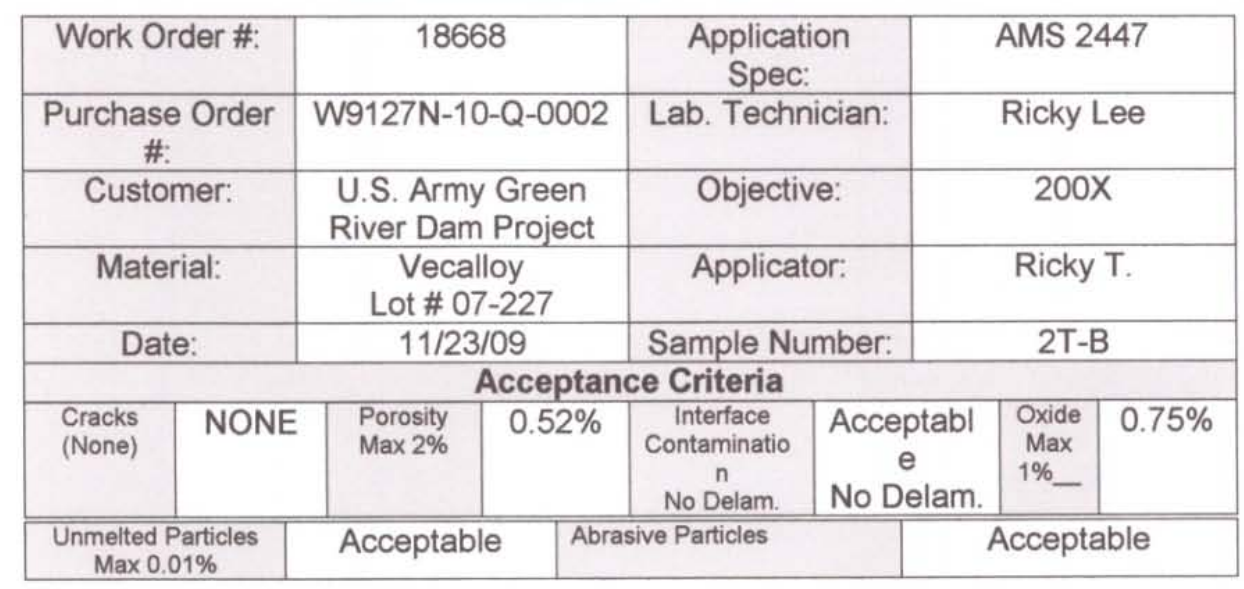
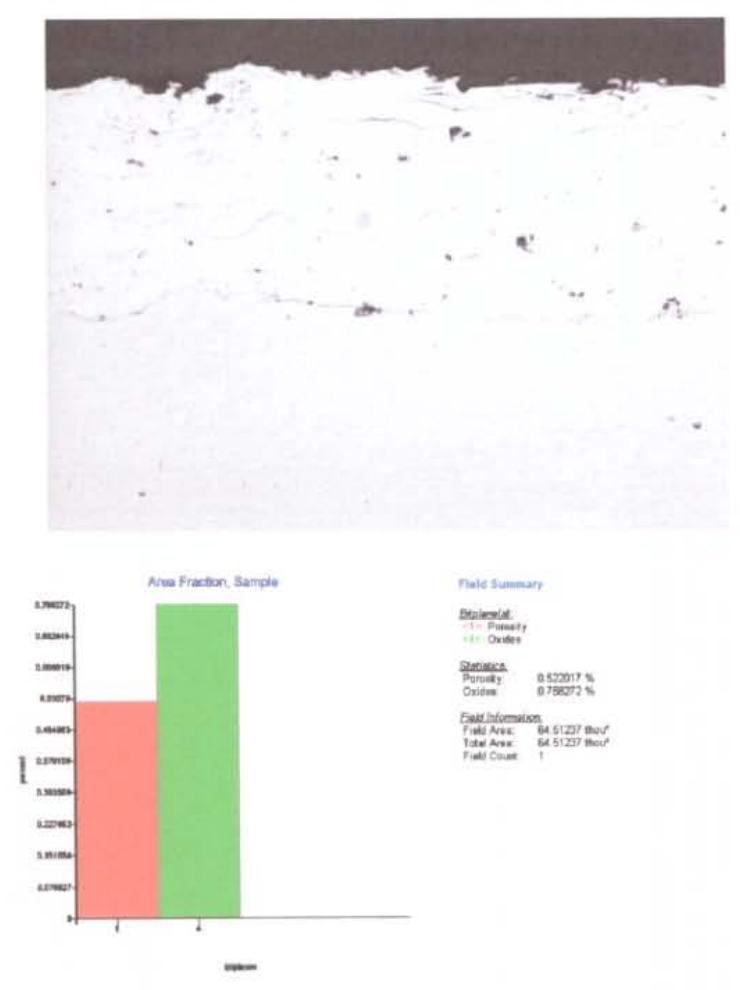


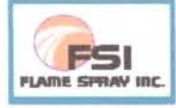

Test Performed

Date:

Lab W/O\#

Sample Number

P.O\#

Customer

Application Spec.

Acceptance Criteria

Total \# of

Measurements
FLAME SPRAY, INC.

4674 Alvarado Canyon Rd.

San Diego, CA. 92120

\begin{tabular}{|c|c|c|c|c|}
\hline No & D1 & D2 & Avg D & HV \\
\hline 1 & 29.79 & 31.12 & 30.46 & 599.80 \\
\hline 2 & 27.01 & 28.37 & 27.69 & 725.57 \\
\hline 3 & 25.28 & 26.95 & 26.12 & 815.73 \\
\hline 4 & 25.78 & 27.02 & 26.40 & 798.21 \\
\hline 5 & 26.84 & 27.3 & 27.07 & 759.19 \\
\hline 6 & 29.74 & 29.78 & 29.76 & 628.14 \\
\hline 7 & 24.8 & 26.41 & 25.61 & 848.55 \\
\hline 8 & 25.38 & 26.14 & 25.76 & 838.36 \\
\hline 9 & 25.58 & 27.03 & 26.31 & 803.99 \\
\hline 10 & 28.16 & 28.02 & 28.09 & 705.05 \\
\hline AVG & & & & 752.26 \\
\hline
\end{tabular}

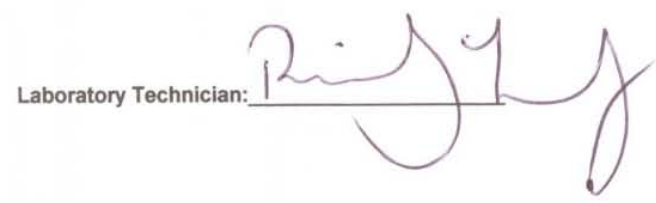

Hardness Test-Vicker Profile $\underline{11 / 24 / 2009}$

18668

18668-2T-B

W9127N-10-Q-0002

U.S. Army Green River $D_{i}$

AMS 2447

500 Min. Avg. 


\begin{tabular}{|c|c|l|}
\hline FuAmE SPFAV Inc. & $\begin{array}{l}\text { Quality Control } \\
\text { Microstructure }\end{array}$ & $\begin{array}{l}\text { Flame Spray Inc. } \\
\text { 4674 Alvarado Canyon } \\
\text { Rd. } \\
\text { San Diego, CA 92120 } \\
\text { Examination Report } \\
\text { 619-283-2007 }\end{array}$ \\
\hline
\end{tabular}

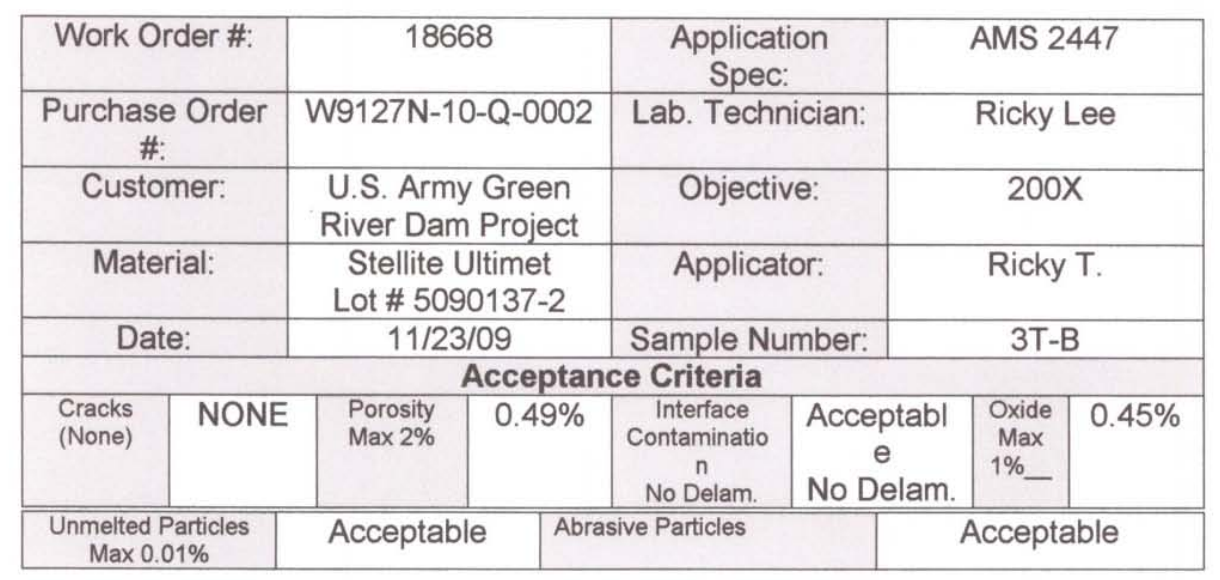
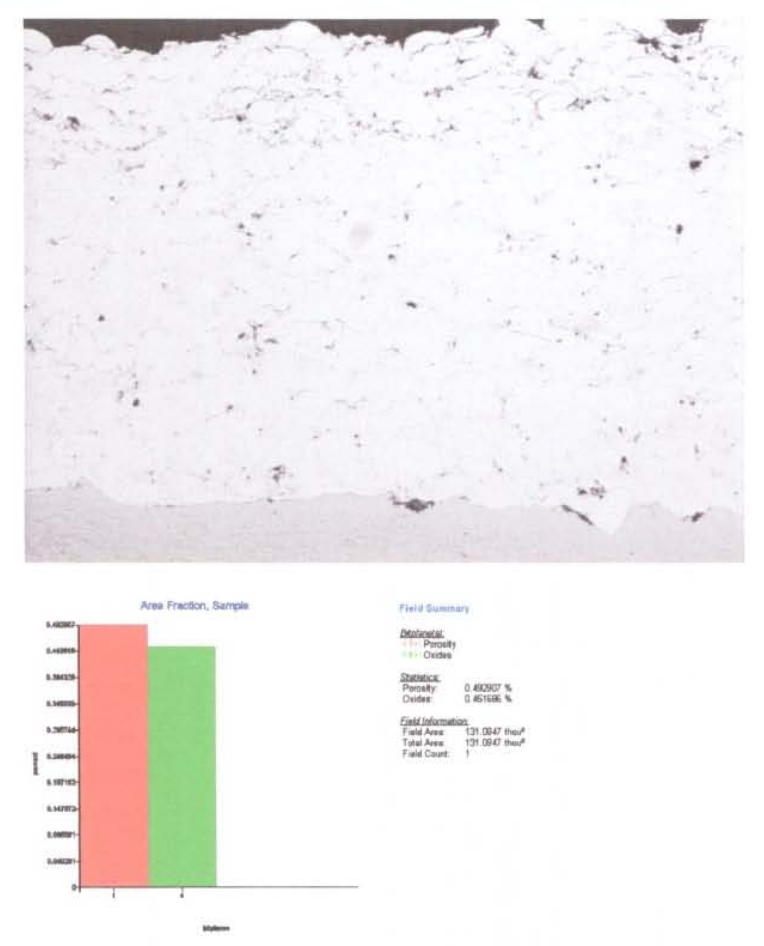


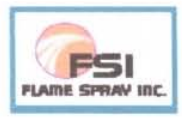

Test Performed

Date:

Lab w/O\#

Sample Number

P.O\#

Customer

Application Spec.

Acceptance Criteria

Total \# of

Measurements
FLAME SPRAY, INC.

4674 Alvarado Canyon Rd.

San Diego, CA. 92120

\begin{tabular}{|c|c|c|c|c|}
\hline No & D1 & D2 & Avg D & HV \\
\hline 1 & 17.93 & 17.46 & 17.70 & 592.25 \\
\hline 2 & 17.41 & 17.2 & 17.31 & 619.24 \\
\hline 3 & 16.74 & 16.64 & 16.69 & 665.72 \\
\hline 4 & 20.23 & 20.72 & 20.48 & 442.34 \\
\hline 5 & 17.82 & 17.67 & 17.75 & 588.91 \\
\hline 6 & 21.15 & 22.68 & 21.92 & 386.12 \\
\hline 7 & 19.26 & 19.33 & 19.30 & 498.10 \\
\hline 8 & 22.41 & 22.87 & 22.64 & 361.79 \\
\hline 9 & 20.21 & 20.08 & 20.15 & 456.95 \\
\hline 10 & 17.94 & 18.34 & 18.14 & 563.55 \\
\hline AVG & & & & 517.50 \\
\hline
\end{tabular}

Laboratory Technician: 


\begin{tabular}{|c|c|l|}
\hline pLame SPrAy inc. & $\begin{array}{l}\text { Quality Control } \\
\text { Microstructure }\end{array}$ & $\begin{array}{l}\text { Flame Spray Inc. } \\
\text { 4674 Alvarado Canyon } \\
\text { Rd. } \\
\text { San Diego, CA } 92120 \\
\text { Examination Report } \\
619-283-2007\end{array}$ \\
\hline
\end{tabular}

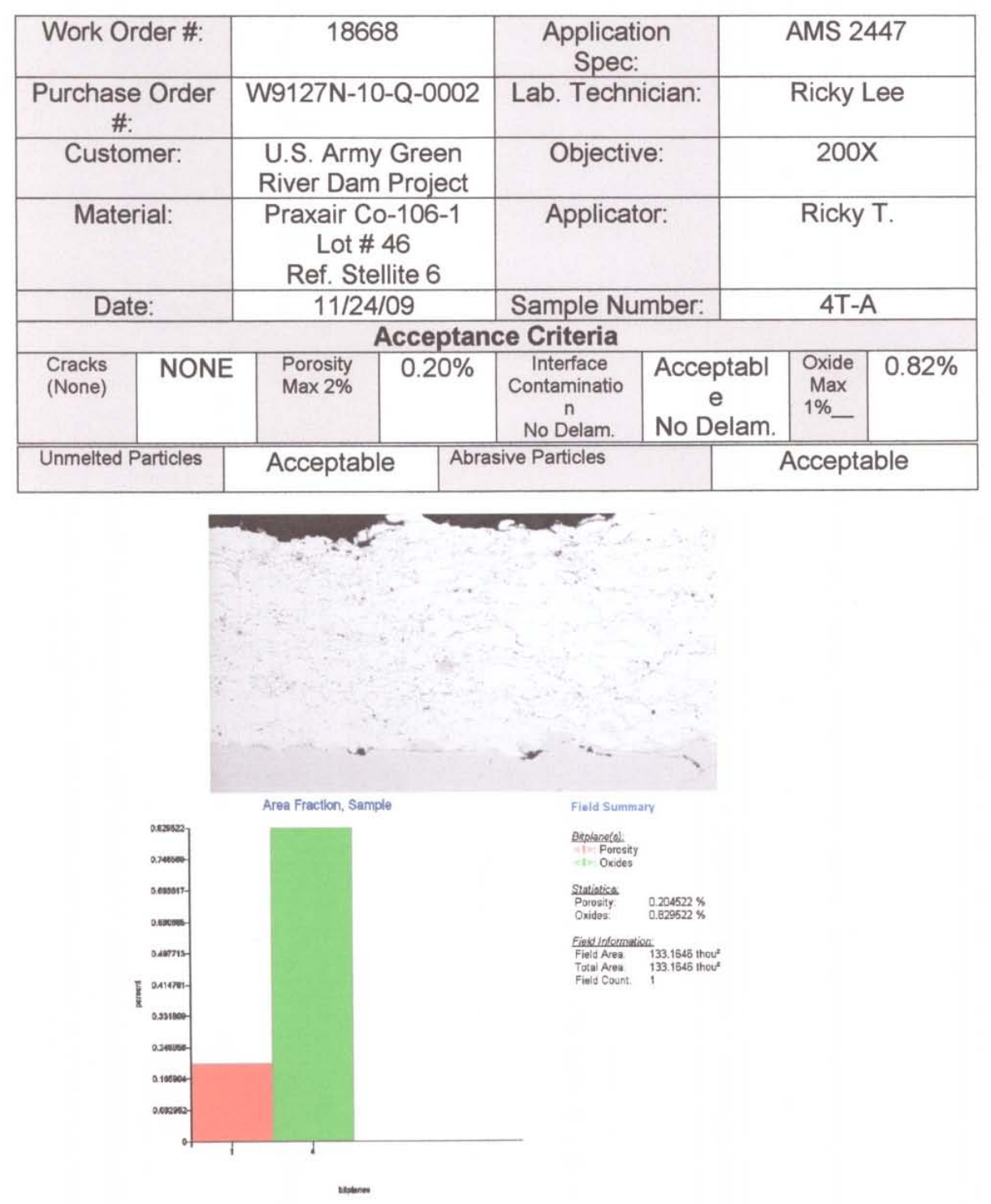




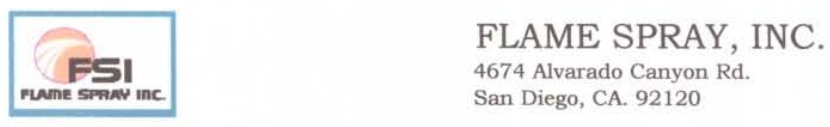

$\begin{array}{ll}\begin{array}{l}\text { Test Performed } \\ \text { Date: }\end{array} & \underline{\text { Hardness Test-Vicker Profile }} \\ \text { Lab w/O\# } & \underline{11 / 24 / 2009} \\ \text { Sample Number } & \underline{18668} \\ \begin{array}{l}\text { P.O\# } \\ \text { Customer }\end{array} & \underline{\text { W9127N-10-Q-0002 }} \\ \begin{array}{l}\text { Application Spec. } \\ \text { Acceptance Criteria }\end{array} & \underline{\text { AMS } 2447} \\ \begin{array}{l}\text { Total \# of } \\ \text { Measurem }\end{array} & \underline{400 \text { Mvg }} . \\ \end{array}$

\begin{tabular}{|c|c|c|c|c|}
\hline No & D1 & D2 & Avg D & HV \\
\hline 1 & 18.43 & 18.76 & 18.60 & 536.30 \\
\hline 2 & 18.78 & 19.83 & 19.31 & 497.58 \\
\hline 3 & 18.45 & 18.43 & 18.44 & 545.36 \\
\hline 4 & 19.37 & 20.5 & 19.94 & 466.63 \\
\hline 5 & 19.05 & 19.68 & 19.37 & 494.50 \\
\hline 6 & 18.78 & 19.36 & 19.07 & 509.92 \\
\hline 7 & 20.76 & 21.56 & 21.16 & 414.16 \\
\hline 8 & 19.45 & 20.2 & 19.83 & 471.82 \\
\hline 9 & 17.85 & 19.36 & 18.61 & 535.73 \\
\hline 10 & 17.99 & 18.19 & 18.09 & 566.66 \\
\hline AVG & & & & 503.87 \\
\hline
\end{tabular}

Laboratory Technician: 


\begin{tabular}{|c|c|l|}
\hline & $\begin{array}{l}\text { Quality Control } \\
\text { Microstructure }\end{array}$ & $\begin{array}{l}\text { Flame Spray Inc. } \\
\mathbf{4 6 7 4} \text { Alvarado Canyon } \\
\text { Rd. } \\
\text { San Diego, CA 92120 } \\
\text { 619-283-2007 }\end{array}$ \\
\hline
\end{tabular}

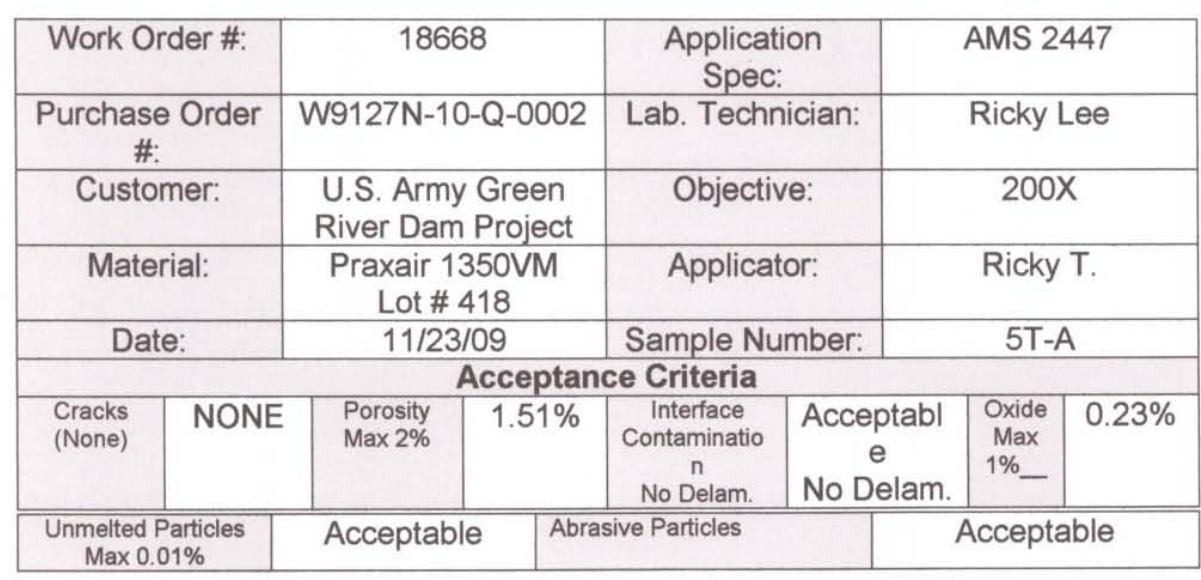
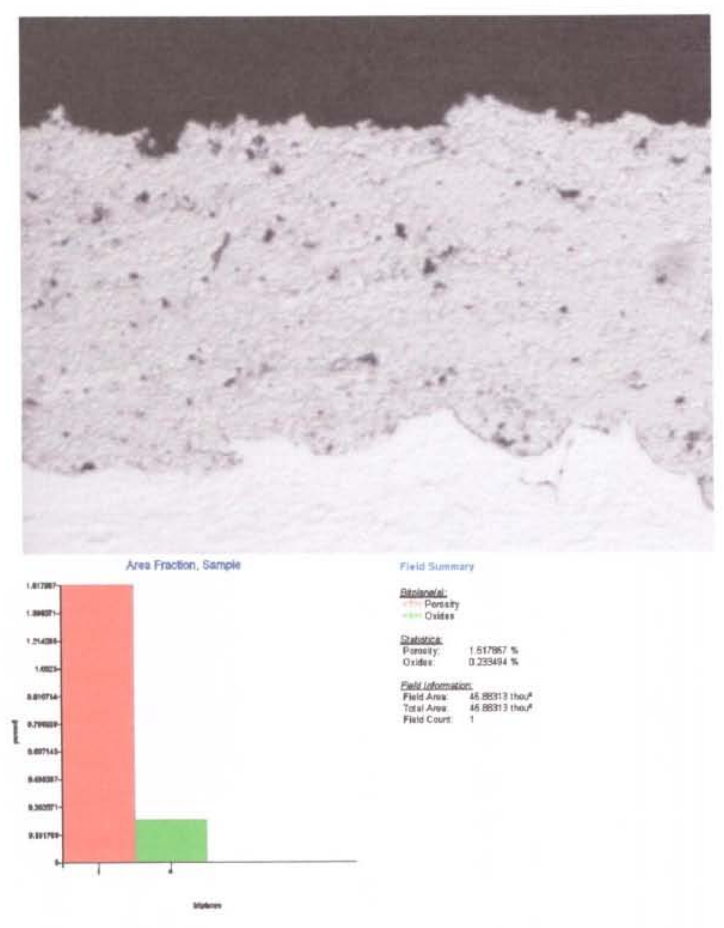


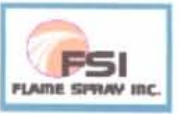

Test Performed

Date:

Lab w/O\#

Sample Number

P.O\#

Customer

Application Spec.

Acceptance Criteria

Total of

Measurements
FLAME SPRAY, INC.

4674 Alvarado Canyon Rd.

San Diego, CA. 92120

\begin{tabular}{|c|c|c|c|c|}
\hline No & D1 & D2 & Avg D & HV \\
\hline 1 & 23.53 & 23.2 & 23.37 & 1019.04 \\
\hline 2 & 20.35 & 20.21 & 20.28 & 1352.66 \\
\hline 3 & 20.58 & 21.32 & 20.95 & 1267.53 \\
\hline 4 & 21.73 & 22.2 & 21.97 & 1153.09 \\
\hline 5 & 25.48 & 26.41 & 25.95 & 826.45 \\
\hline 6 & 22.16 & 23.09 & 22.63 & 1086.79 \\
\hline 7 & 20.19 & 20.53 & 20.36 & 1342.05 \\
\hline 8 & 21.6 & 22.33 & 21.97 & 1153.09 \\
\hline 9 & 22.16 & 22.59 & 22.38 & 1111.22 \\
\hline 10 & 24.05 & 24.76 & 24.41 & 934.04 \\
\hline AVG & & & & 1124.60 \\
\hline
\end{tabular}

Laboratory Technician: 1 


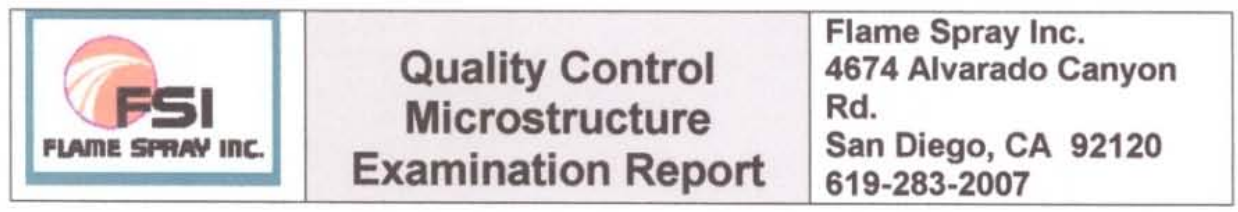

\begin{tabular}{|c|c|c|c|c|c|c|c|c|}
\hline \multicolumn{2}{|c|}{ Work Order \#: } & \multicolumn{2}{|c|}{18668} & \multicolumn{2}{|c|}{$\begin{array}{l}\text { Application } \\
\text { Spec: }\end{array}$} & \multicolumn{3}{|c|}{ AMS 2447} \\
\hline \multicolumn{2}{|c|}{$\begin{array}{c}\text { Purchase Order } \\
\# \text { : }\end{array}$} & \multicolumn{2}{|c|}{ W9127N-10-Q-0002 } & \multicolumn{2}{|c|}{ Lab. Technician: } & \multicolumn{3}{|c|}{ Ricky Lee } \\
\hline \multicolumn{2}{|c|}{ Customer: } & \multicolumn{2}{|c|}{$\begin{array}{l}\text { U.S. Army Green } \\
\text { River Dam Project }\end{array}$} & \multicolumn{2}{|c|}{ Objective: } & \multicolumn{3}{|c|}{$200 x$} \\
\hline \multicolumn{2}{|c|}{ Material: } & \multicolumn{2}{|c|}{$\begin{array}{c}\text { Amperit } 588.074 \\
\text { Lot \# } 4100900\end{array}$} & \multicolumn{2}{|c|}{ Applicator: } & \multicolumn{3}{|c|}{ Ricky T. } \\
\hline \multicolumn{2}{|c|}{ Date: } & \multicolumn{2}{|c|}{$11 / 23 / 09$} & \multicolumn{2}{|c|}{ Sample Number: } & \multicolumn{3}{|c|}{$6 \mathrm{~T}-\mathrm{A}$} \\
\hline \multicolumn{9}{|c|}{ Acceptance Criteria } \\
\hline $\begin{array}{l}\text { Cracks } \\
\text { (None) }\end{array}$ & NONE & $\begin{array}{l}\text { Porosity } \\
\text { Max 2\% }\end{array}$ & $1.84 \%$ & $\begin{array}{c}\text { Interface } \\
\text { Contaminatio } \\
n \\
\text { No Delam. }\end{array}$ & \multicolumn{2}{|c|}{$\begin{array}{c}\text { Acceptabl } \\
e \\
\text { No Delam. }\end{array}$} & \begin{tabular}{|l|} 
Oxide \\
Max \\
$1 \% \ldots$
\end{tabular} & $0.56 \%$ \\
\hline \multicolumn{2}{|c|}{$\begin{array}{c}\text { Unmelted Particles } \\
\text { Max } 0.01 \%\end{array}$} & \multicolumn{2}{|c|}{ Acceptable } & ive Particles & & \multicolumn{3}{|c|}{ Acceptable } \\
\hline
\end{tabular}
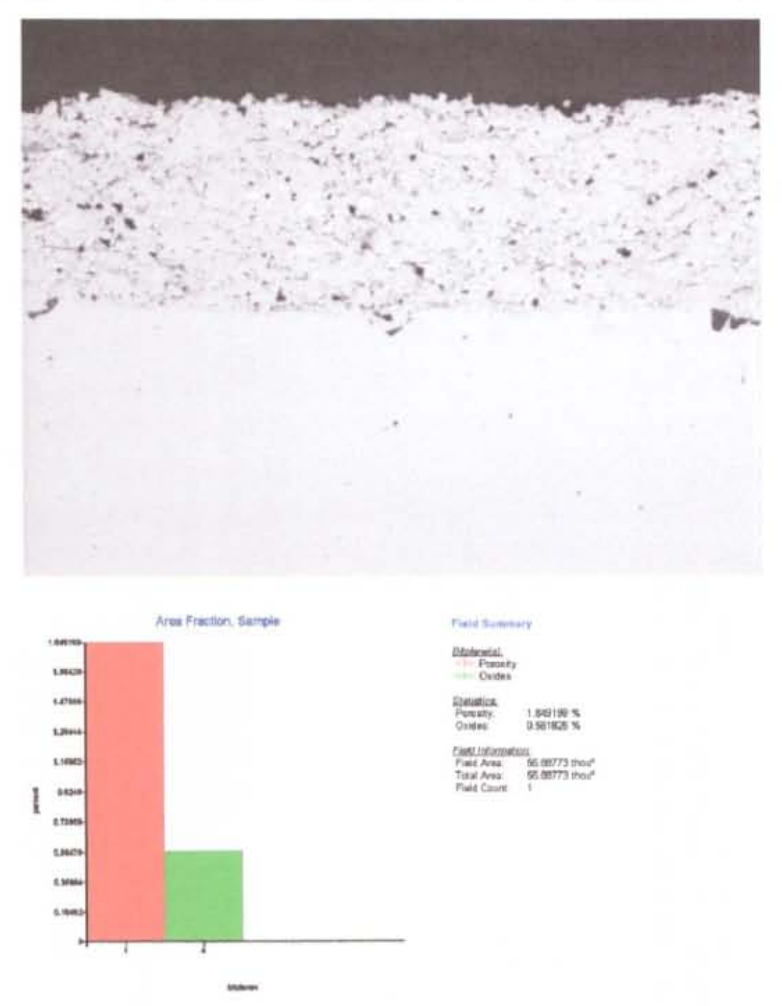


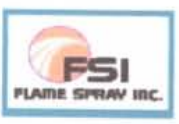

Test Performed

Date:

Lab w/O"

Sample Number

P.O\#

Customer

Application Spec.

Acceptance Criteria

Total $\#$ of

Measurements
FLAME SPRAY, INC.

4674 Alvarado Canyon Rd.

San Diego, CA. 92120

\begin{tabular}{|c|c|c|c|c|}
\hline No & D1 & D2 & Avg D & HV \\
\hline 1 & 15.38 & 15.37 & 15.38 & 784.46 \\
\hline 2 & 15.34 & 14.52 & 14.93 & 831.92 \\
\hline 3 & 14.96 & 15.18 & 15.07 & 816.54 \\
\hline 4 & 14.83 & 14.68 & 14.76 & 851.78 \\
\hline 5 & 13.64 & 13.96 & 13.80 & 973.75 \\
\hline 6 & 13.74 & 14.85 & 14.30 & 907.48 \\
\hline 7 & 13.64 & 12.74 & 13.19 & 1065.89 \\
\hline 8 & 15.26 & 15.72 & 15.49 & 772.86 \\
\hline 9 & 15.67 & 15.03 & 15.35 & 787.02 \\
\hline 10 & 14.32 & 15.24 & 14.78 & 848.90 \\
\hline AVG & & & & 864.06 \\
\hline
\end{tabular}
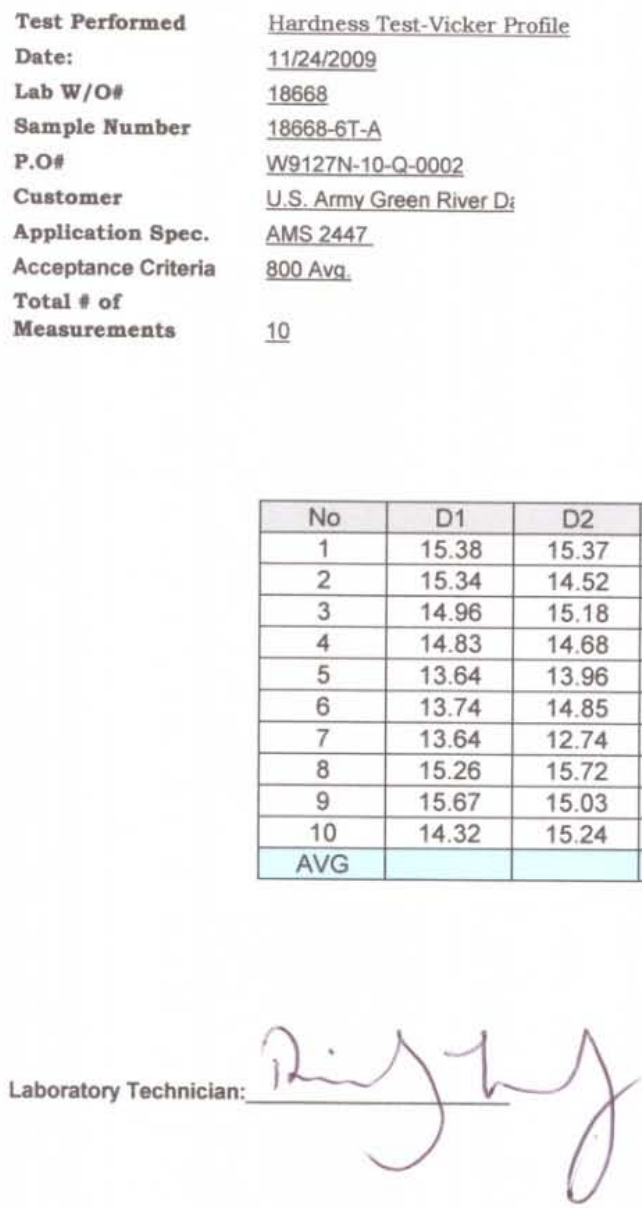


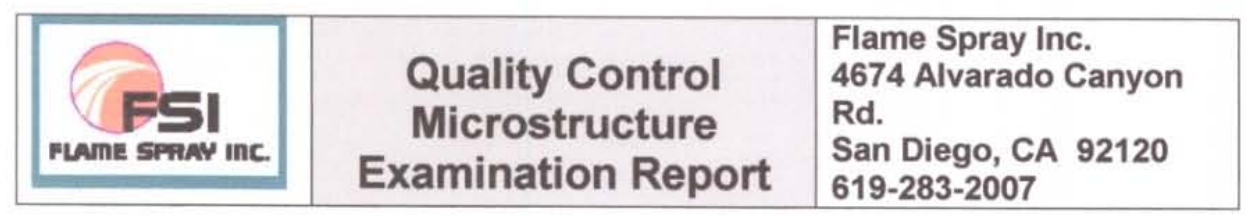

\begin{tabular}{|c|c|c|c|c|c|c|c|c|}
\hline \multicolumn{2}{|c|}{ Work Order \#: } & \multicolumn{2}{|c|}{18668} & \multicolumn{2}{|c|}{$\begin{array}{l}\text { Application } \\
\text { Spec: }\end{array}$} & \multicolumn{3}{|c|}{ AMS 2447} \\
\hline \multicolumn{2}{|c|}{$\begin{array}{c}\text { Purchase Order } \\
\#:\end{array}$} & \multicolumn{2}{|c|}{ W9127N-10-Q-0002 } & \multicolumn{2}{|c|}{ Lab. Technician: } & \multicolumn{3}{|c|}{ Ricky Lee } \\
\hline \multicolumn{2}{|c|}{ Customer: } & \multicolumn{2}{|c|}{$\begin{array}{l}\text { U.S. Army Green } \\
\text { River Dam Project }\end{array}$} & \multicolumn{2}{|c|}{ Objective: } & \multicolumn{3}{|c|}{$200 x$} \\
\hline \multicolumn{2}{|c|}{ Material: } & \multicolumn{2}{|c|}{$\begin{array}{l}\text { Amperit } 584.1 \\
\text { Lot \# } 4220840\end{array}$} & \multicolumn{2}{|c|}{ Applicator: } & \multicolumn{3}{|c|}{ Ricky T. } \\
\hline \multicolumn{2}{|c|}{ Date: } & $11 / 23$ & & Sample Nu & mber: & & $7 \mathrm{~T}-\mathrm{B}$ & \\
\hline \multicolumn{9}{|c|}{ Acceptance Criteria } \\
\hline $\begin{array}{l}\text { Cracks } \\
\text { (None) }\end{array}$ & NONE & $\begin{array}{l}\text { Porosity } \\
\text { Max 2\% }\end{array}$ & $1.89 \%$ & \begin{tabular}{|c|} 
Interface \\
Contaminatio \\
$n$ \\
No Delam. \\
\end{tabular} & \multicolumn{2}{|c|}{$\begin{array}{c}\text { Acceptabl } \\
e \\
\text { No Delam. }\end{array}$} & \begin{tabular}{c|} 
Oxide \\
Max \\
$1 \% \_$
\end{tabular} & $0.89 \%$ \\
\hline \multicolumn{2}{|c|}{$\begin{array}{l}\text { Unmelted Particles } \\
\text { Max } 0.01 \%\end{array}$} & \multicolumn{2}{|c|}{ Acceptable } & sive Particles & & \multicolumn{3}{|c|}{ Acceptable } \\
\hline
\end{tabular}
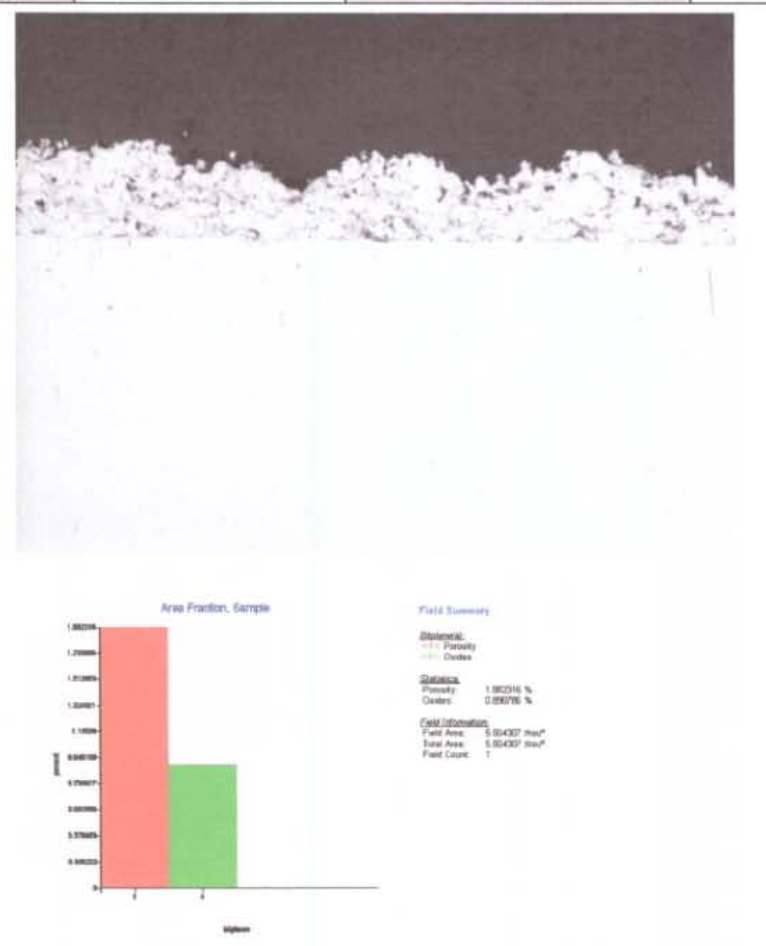
FLAME SPRAY, INC.

4674 Alvarado Canyon Rd.

San Diego, CA. 92120

\begin{tabular}{|c|c|}
\hline Test Performed & $\underline{\text { Hardness Test-Vicker Profile }}$ \\
\hline Date: & $11 / 24 / 2009$ \\
\hline Lab w/Ot & $\underline{18668}$ \\
\hline Sample Number & $18668-7 T-B$ \\
\hline P.O\# & W9127N-10-Q-0002 \\
\hline Customer & $\underline{\text { U.S. Army Green River Di }}$ \\
\hline Application Spec. & AMS 2447 \\
\hline Acceptance Criteria & 800 Avg. \\
\hline $\begin{array}{l}\text { Total } \neq \text { of } \\
\text { Measurements }\end{array}$ & 10 \\
\hline
\end{tabular}

\begin{tabular}{|c|c|c|c|c|}
\hline No & D1 & D2 & Avg D & HV \\
\hline 1 & 15.31 & 15.35 & 15.33 & 789.08 \\
\hline 2 & 15.36 & 15.3 & 15.33 & 789.08 \\
\hline 3 & 13.3 & 13.59 & 13.45 & 1025.85 \\
\hline 4 & 14.8 & 15.35 & 15.08 & 816.00 \\
\hline 5 & 13.58 & 12.84 & 13.21 & 1062.67 \\
\hline 6 & 12.81 & 12.75 & 12.78 & 1135.38 \\
\hline 7 & 12.89 & 13.68 & 13.29 & 1050.70 \\
\hline 8 & 16.22 & 15.04 & 15.63 & 759.08 \\
\hline 9 & 13.9 & 14.63 & 14.27 & 911.30 \\
\hline 10 & 16.59 & 17.05 & 16.82 & 655.47 \\
\hline AVG & & & & 899.46 \\
\hline
\end{tabular}

Laboratory Technician: 


\begin{tabular}{|c|c|l|}
\hline rLame SPAN inc. & $\begin{array}{l}\text { Quality Control } \\
\text { Microstructure }\end{array}$ & $\begin{array}{l}\text { Flame Spray Inc. } \\
\mathbf{4 6 7 4} \text { Alvarado Canyon } \\
\text { Rd. } \\
\text { San Diego, CA 92120 } \\
\text { Examination Report } \\
\text { 619-283-2007 }\end{array}$ \\
\hline
\end{tabular}

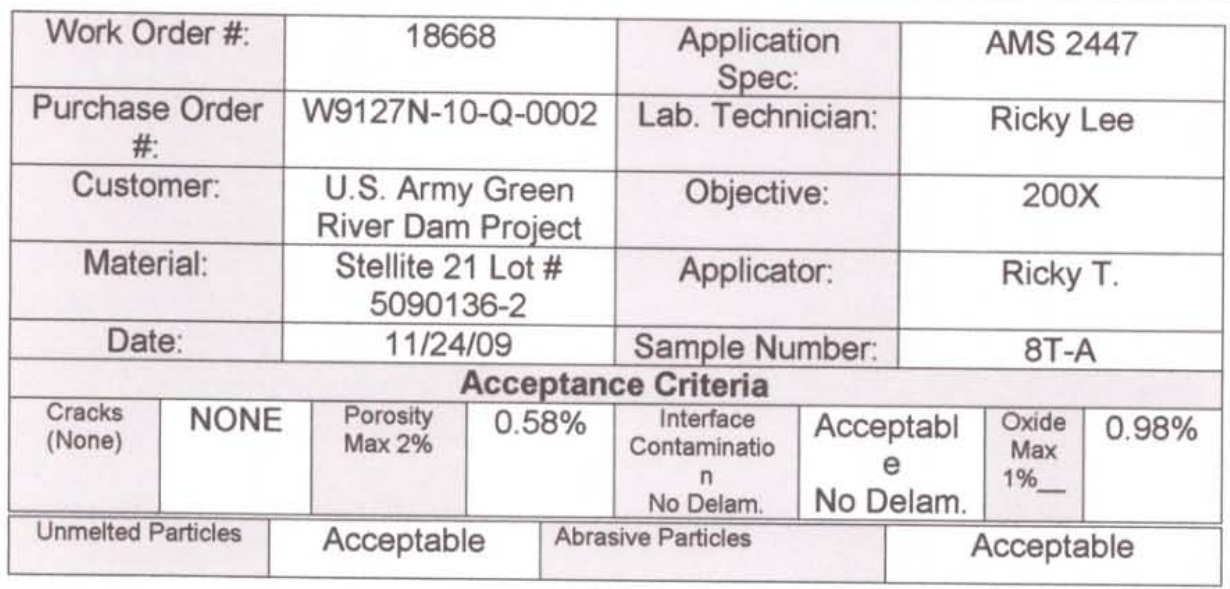
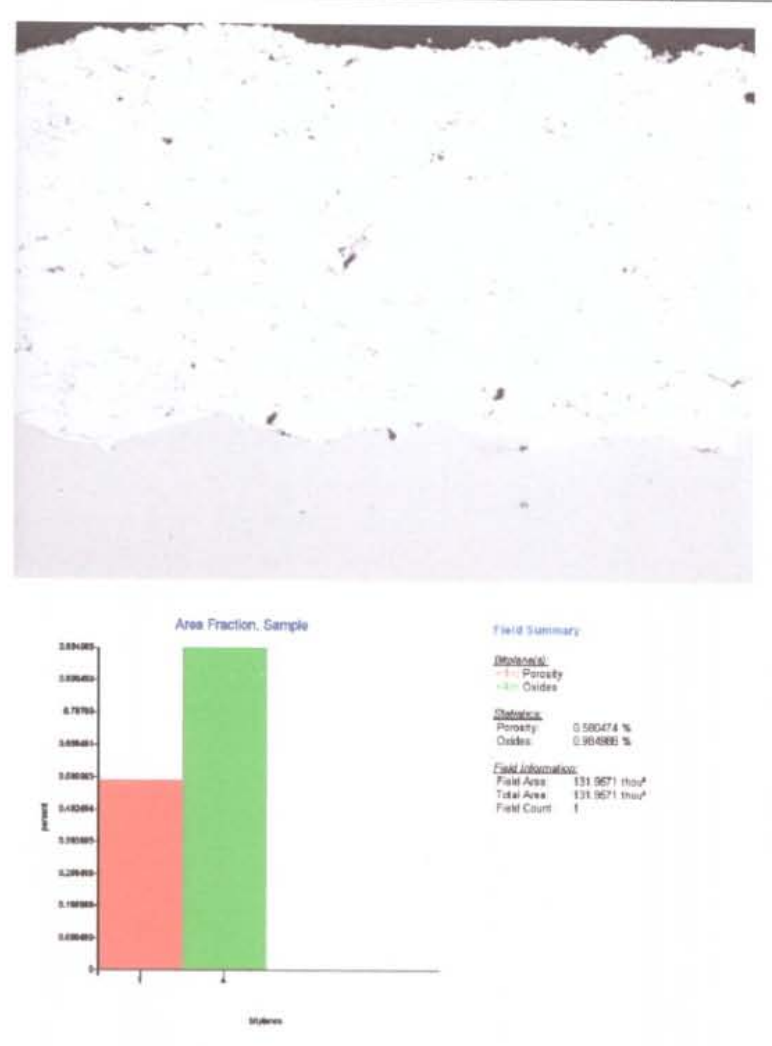


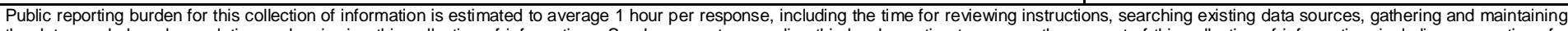

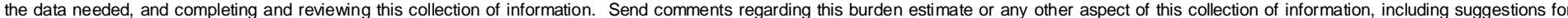

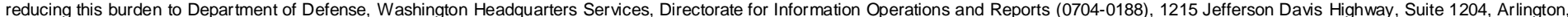

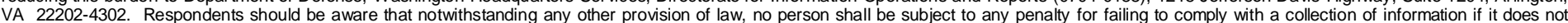
display a currently valid OMB control number. PLEASE DO NOT RETURN YOUR FORM TO THE ABOVE ADDRESS.

\section{REPORT DATE (DD-MM-YYYY) 30Jun2011}

\section{TITLE AND SUBTITLE}

Cavitation-Resistant Coatings for Hydropower Turbines
3. DATES COVERED (From - To)

5a. CONTRACT NUMBER

5b. GRANT NUMBER

5c. PROGRAM ELEMENT NUMBER

5d. PROJECT NUMBER

Ryan Sollars and Alfred D. Beitelman 5e. TASK NUMBER

5f. WORK UNIT NUMBER

\section{PERFORMING ORGANIZATION NAME(S) AND} ADDRESS(ES)

US Army Corps of Engineers, Portland Dist. Hydroelectric Design Center 333 SW First Avenue Portland, Oregon 97204-3440

\section{SPONSORING I MONITORING AGENCY NAME(S) AND ADDRESS(ES)}

Headquarters

US Army Corps of Engineers

Washington, DC 20314-1000
US Army Engineer Research and

Development Center

Construction Engrg Research Laboratory 2902 Newmark Drive

Champaign, IL 61826-1076
8. PERFORMING ORGANIZATION REPORT NUMBER

ERDC/CERL TR-11-21

10. SPONSOR/MONITOR'S ACRONYM(S)

11. SPONSOR/MONITOR'S REPORT NUMBER(S)

\section{DISTRIBUTION / AVAILABILITY STATEMENT}

Approved for public release; distribution is unlimited.

\section{SUPPLEMENT ARY NOTES}

\section{ABSTRACT}

Operating hydropower turbines to obtain the ultimate power output often results in cavitation (the rapid formation and collapse of vapor pockets in a flowing liquid in regions of very low pressure) in the turbine area. The level of cavitation typically destroys organic coatings in a relatively short time. Traditional metallizing to repair cavitation damage has resulted in unsatisfactory performance. Other coating systems, such as those deposited by High Velocity Oxygen Flame (HVOF), have been laboratory tested and shown to hold promise but have not been evaluated in actual long-term field applications.

This study evaluated HVOF-applied coating systems that hold promise for long-term cavitation resistance and apply the most promising products to turbine areas for long-term field performance data. Work consisted of evaluating existing published and unpublished data on cavitation-resistant materials and selecting the most promising systems for field application. Those systems were then applied to areas of a turbine to evaluate their long-term performance.

After 1 year, it is clear that many of the coatings have failed. Two of the coatings, however, appear to be virtually unchanged from the time of application and may be found to provide long-term resistance to damage caused by cavitation.

\section{SUBJECT TERMS}

Cavitation, Hydropower turbines, Protective coatings

\section{SECURITY CLASSIFICATION OF:}

a. REPORT

$\mathrm{U}$ b. ABSTRACT

$\mathrm{U}$ c. THIS PAGE

$\mathrm{U}$

\begin{tabular}{c|c}
$\begin{array}{c}\text { 17. LIMITATION } \\
\text { OF ABSTRACT }\end{array}$ & $\begin{array}{c}\text { 18. NUMBER } \\
\text { OF PAGES }\end{array}$ \\
U & 67
\end{tabular}

19a. NAME OF RESPONSIBLE PERSON

19b. TELEPHONE NUMBER (include area code) 